\title{
Tüketicilerin Satın Alma Tarzlarının Mobil Satın Alma Niyetine Etkisinde Sosyal Medya Reklamlarının Aracılık Rolü
}

\author{
The Mediation Role of Social Media Advertisements in Effect of Consumers' \\ Purchasing Styles on the Mobile Purchasing Intentions
}

\section{Volkan ÖNGEL ${ }^{1}$, Aziz Mücahit BAKIR ${ }^{2}$, Hasan Sadık TATLI ${ }^{3}$}

\begin{abstract}
$\ddot{\mathbf{O z}}$
Amaç: Çalışmanın amacı, tüketicilerin satın alma tarzlarının mobil satın alma niyeti üzerindeki etkisinde, sosyal medya reklamlarının aracılık rolünün tespit edilmesidir.

Tasarım/Yöntem: Mobil cihaza sahip ve sosyal medya uygulamalarından en az bir tanesini kullanan tüketiciler araștırmanın evrenini oluştururken, çevrimiçi anket yöntemiyle ulaşılan 1162 tüketici ise örneklemi olusturmaktadır. Verilerin analizi için SPSS 25 paket programı ve SPSS Process 2.16 makrosu kullanılmıştır. Bulgular: Araştırma sonuçlarına göre, tüketicilerin satın alma tarzlarının alt boyutlarının mobil cihazları kullanarak satın alma niyetlerini olumlu yönde etkilediği, sosyal medya reklamlarının özelliklerinin ise bu etkide aracılık rolünün olduğu tespit edilmiștir Ayrıca sosyal medya reklamlarının mobil satın almaya olan etkisinin, tüketicilerin satın alma tarzlarının mobil satın almaya etkisinden daha yüksek düzeyde olduğu tespit edilmiştir.

Sınırlılıklar: Araştırma, sosyal medya kullanımı sağlayan, mobi cihazlara sahip tüketiciler açısından yapılmıştır. Ayrıca çalışma nicel tekniklerle gerçekleştirilmiş ve verilerin normal dağılımı sağladığı varsayılmıştır.

Özgünlük/Değer: Alanyazında tüketicilerin mobil cihazlar aracılığı ile satın alma işlemi gerçekleştirmesini açıklayan modeller bulunmakla birlikte, bu satın alma davranısında tüketici tarzları ve sosyal medya reklamlarının rolünü açıklayan bir çalışmaya ise rastlanamamıştır. Araştırma, eksikliği gidermesi açısından diğer araștırmalardan farklılașmaktadır.

Anahtar Kelimeler: Tüketici Satın Alma Tarzları, Sosyal Medya Reklamları, Mobil Satın Alma Niyeti
\end{abstract}

\section{Abstract}

Purpose: The study aims to determine the mediating role of social media ads in consumers' purchasing styles on mobile purchasing intention.

Design/Method: Consumers who have a mobile device and use at least one of the social media applications constitute the research universe, while 1162 consumers reached through the online questionnaire form the sample. SPSS 25 package program and SPSS Process 2.16 macro were used for data analysis.

Results: According to the research results, it was determined that the sub-dimensions of the purchasing style of consumers positively affect their purchasing intention using mobile devices, and the characteristics of social media ads have a mediating role in this effect. It has also been found that the effect of social media ads on mobile purchasing is higher than the effect of consumers' buying style on mobile purchasing.

Limitations: The research was conducted for consumers who use social media and have mobile devices. The study is also conducted with quantitative techniques, and it is assumed that the data provide a normal distribution.

Originality/Value: In the literature, although there are models that explain the purchasing process of consumers via mobile devices, there is no study that explains the role of consumer styles and social media ads in this purchasing behavior. The research differs from other studies in terms of overcoming this deficiency.

Keywords: Consumer Purchasing Styles, Social Media Advertisements, Mobile Purchasing Intention

\footnotetext{
1 Prof. Dr., Beykent Üniversitesi, İktisadi İdari Bilimler Fakültesi, Uluslararası Ticaret ve Finansman Bölümü, volkanongel@beykent.edu.tr, ORCID: 0000-0001-8881-2465

${ }^{2}$ Arş. Gör., Beykent Üniversitesi, İktisadi İdari Bilimler Fakültesi, İşletme (Türkçe) Bölümü, mucahitbakir@ beykent.edu.tr, ORCID: 0000-0001-6714-1703

${ }^{3}$ Arş. Gör., Beykent Üniversitesi, İktisadi İdari Bilimler Fakültesi, İşletme (İngilizce) Bölümü, hasantatli@beykent.edu.tr, ORCID: 0000-0003-1918-3188
} 


\section{GIRISS}

Teknolojinin gelişimi hayatın her alanında etkili olmaktadır. Mobil cihazların kullanımlarının artması teknolojik ilerlemenin en yaygın etkisi olarak görülmektedir. İlk mobil cihazlarda bulunan ses ve yazı özelliklerine yıllar geçtikçe yenileri eklenmiştir. 2000'li yıllarda mobil cihazların internet ile buluşması, mobil cihazların iletişim aracı olmakla sınırlı kalmamasını, kullanıcıların ihtiyaçlarını giderme şekillerinde de yenilik içeren özellikler sunmasını sağlamıştır. Görüntülü konuşma, sipariş verme, belge düzenleme, sosyal ağlar üzerinden sosyalleşme bunlara örnek olarak verilebilir. Mobil cihazların yeni özellikleri pazarlama alanında da yeni uygulamaların hayata geçirilmesine olanak sağlamıştır. Bir nevi "avuç içindeki marka" tabiri, pazarlama faaliyetlerinde mobil cihazların tüketicilere ulaşma açısından sağladığı avantajları özetlemektedir. Geleneksel pazarlama metotlarında tek taraflı olan iletişim, mobil cihazlarla iki yönlü iletişime dönüşmüş, çevrimiçi alışveriş deneyimi yoğun bir şekilde kullanılmaya başlanmıştır.

Mobil cihazların artan kullanımı, sosyal medya kullanımını da artırmıştır. Sosyal medya; platformda yer alan kullanıcıların fikirlerini, görüşlerini diğer kullanıcılarla paylaşmayı, sosyal bir a oluşturarak ağ içerisinde etkileşim halinde olmayı sağlayan çevrimiçi topluluklar olarak tanımlanmaktadır (Keating vd., 2016). Mobil cihazlar, çevrimiçi toplulukların mekâna ve zamana bağlı kalmadan, sürekli etkileşim halinde olmalarını sağlamıştır. Söz konusu etkileşim sadece kullanıcılar arasında kalmamış, işletmelerin markaları ve ürünleri hakkında sayfalar oluşturma ve reklam verme gibi pazarlama amaçlı faaliyetlerin yapılmasına da olanak sağlamıştır. Çevrimiçi topluluklarda tüketiciler işletmelere ait profilleri takip edip, mal ve hizmetleri hakkında detaylı bilgilere erişebilmektedir. Bununla beraber işletmeler tüketicilerin işletmeye ait olan profil veya sayfaları takip etmesini beklemeden sosyal medya uygulamalarında reklam oluşturarak pazarlama faaliyetlerini gerçekleştirmektedir. Tüketicilerin istediği ya da ihtiyaç duyduğu ürünlerin reklamlarla tüketiciye hatırlatılması, ürüne karşı farkındalık oluşturulması, tüketicinin alışveriş sürecine yönelmesini sağlayabilmektedir. Özellikle tüketicilerin satın alma tarzlarının farklı olması ve sosyal medya reklamlarının farklı özelliklere sahip olması tüketicilerin mobil cihazları ile satın alma işlemi gerçekleştirme eğilimleri açısından önemli unsurlara dönüşmektedir. Özellikle, tüm dünyayı etkisi altına alan Covid-19 pandemisi ile birlikte, tüketiciler çevrimiçi ve çevrimiçi kanallar üzerinden daha fazla alışveriş yapmak zorunda kalmaktadır. Bütün destekleyici unsurlar bir arada değerlendirildiğinde, tüketicilerin farklı satın alma eğilimlerinin mobil satın alma niyetleri üzerinde etkili olacağı, sosyal medya reklamlarının da söz konusu etki üzerinde bir role sahip olacağını ifade etmek mümkündür. Sosyal medya reklamlarının tüketicilerin satın alma niyeti, marka algısı vb. üzerine etkileri ile ilgili olarak alanyazında bazı çalışmalar bulunmaktadır. Çalışmalardan bazıları tüketicilerin satın alma tarzlarının çevrimiçi kanallardan ya da mobil kanallardan satın almaya etkisini araştırırken, bazı çalışmalar ise sosyal medya reklamlarının mobil satın alma niyetine etkisini incelemektedir. Ancak kişilik özelliklerinin mobil satın alma üzerindeki etkisi ve söz konusu etkide sosyal medya reklamlarının rolünün ne olduğunu araştıran bir çalışmaya ulaşılamamıştır. Alanyazındaki eksiklik ve yukarıda yer alan öngörülerden hareketle araştırmanın amacı "tüketicilerin satın alma tarzlarının, mobil satın almaya etkisinde sosyal medyanın rolünün incelenmesi" olarak belirlenmiştir. Araştırmanın amacına bağlı olarak elde edilecek sonuçlar, tüketicilerin satın alma eğilimleri, sosyal medya reklamları hakkındaki görüşleri ve bunlara bağlı olarak mobil cihazlardan yapılacak olan satın alma eğilimine 1şık tutması açısından önem taşımaktadır. Öyle ki, yoğun bir kullanım alanına sahip olan mobil cihazların satın alma aracı olarak kullanılmasını etkileyen bazı unsurlar aydınlatılmış olacaktır. Daha önceki çalışmaların benzer bir modelleme ile yapılmamış olması nedeniyle, bu araştırma keşfedici özellikler taşımaktadır. Araştırma nicel tekniklerle gerçekleştirilmektedir. Araştırmanın belirli mal, hizmet veya markaya yönelik gerçekleştirilmemesi ve genel tüketicileri içermemesi araştırmanın kısıtlarını oluşturmaktadır.

\section{KAVRAMSAL ÇERÇEVE}

Kavramsal çerçeve başlı̆̆ altında tüketicilerin satın alma esnasında sergiledikleri eğilimler, mobil reklamların özellikleri ve mobil cihazları kullanarak satın alma eğilimleri hakkında alanyazın sunulmaktadır. Ayrıca alanyazında yer alan çalışmaların sonuçları ve çıkarımları kullanılarak araştırmanın hipotezleri oluşturularak bu bölümde sunulmaktadır. 


\subsection{Tüketici Satın Alma Tarzları}

Tüketicilerin davranışlarını açıklamaya ve tahmin etmeye yönelik yapılan araştırmalar, tüketicilerin niçin ve ne şekilde satın alma eylemi gerçekleştirdiklerini tespit etmeye odaklanmaktadır. Böylece ihtiyaç ve isteklere göre tüketicilerin benzer gruplara ayrılması, tüketicilere yönelik olarak hazırlanan pazarlama stratejilerinin belirlenmesinde etkili olmaktadır. Tüketicilerin gruplara ayrılmasında demografik, psikografik, coğrafik, sosyo-ekonomik vb. kriterler kullanılabilmektedir. Tüketicilerin gruplara ayrılmasında kullanılan bir diğer kriter ise satın almada karar verme tarzıdır. Sproles ve Kendall (1986) tarafından gerçekleştirilen araştırmada daha önceden tanımlanan duyusal ve bilişsel özellikleri içeren temel sekiz zihinsel özellik belirlenmiştir. Yazarlar, 40 sorudan oluşan Tüketici Tarzları Envanterinde tüketici satın alma tarzlarını; mükemmeliyetçiler, marka odaklılar, moda odaklılar, eğlence odaklılar, fiyat odaklılar, dürtüsel alışveriş eğilimliler, karmaşa yaşayanlar ve rutin alışveriş yapanlar olmak üzere sekiz ana boyutta tanımlanmışlardır. Araştırmacılar tarafından, tüketicilerin satın alma esnasında karar verme tarzlarının söz konusu özelliklerin bir kombinasyonu olduğu ileri sürülmüştür (Sproles \& Kendall, 1986). Tablo 1'de tüketici tarzlarının öne çıkan özellikleri gösterilmiştir.

Tablo 1: Tüketici Satın Alma Tarzları

\begin{tabular}{ll}
\hline Tüketici Tarzı & Tüketici Tarzının Öne Çıkan Özellikleri \\
\hline Mükemmeliyetçiler & $\begin{array}{l}\text { Bir ürünün “yeterince iyi” olması, mükemmeliyetçi tüketicileri tatmin etmez. Tercihlerinde dikkatli, } \\
\text { sistematik ve kıyaslama yoluyla alışveriş yapmaları beklenir. }\end{array}$ \\
\hline Marka Odaklılar & $\begin{array}{l}\text { Marka odaklılar, yüksek fiyatlı, iyi bilinen markaların daha kaliteli olduğu algısıyla fiyat = kalite } \\
\text { mantığına sahiptirler. En çok reklamı yapılan markalardan alışveriş yapmaları beklenir. }\end{array}$ \\
\hline Eğlence Odaklılar & $\begin{array}{l}\text { Hedonistik alışveriş eğiliminde olan tüketicilerdir. Eğlence odaklılar, alışverişi sadece eğlenmek ve } \\
\text { keyif almak amacıyla yapmaktadırlar. }\end{array}$ \\
\hline Fiyat Odaklılar & $\begin{array}{l}\text { Fiyat bilincine sahip tüketici tarzıdır. Fiyat odaklılar, fiyat araştırması yaparak en uygun fiyatlı olanları } \\
\text { tercih etme eğilimindedirler. Paraları için en iyi değeri elde etme ve alışverişlerinde kıyaslama yapma } \\
\text { eğilimleri yüksektir. }\end{array}$ \\
\hline Dürtüsel Alışveriş & $\begin{array}{l}\text { Dürtüsel ve plansız alışveriş yapma eğilimindeki tüketici grubudur. Alışveriş esnasında harcama } \\
\text { miktarları ve alışverişin iyi ya da kötü bir deneyim olması ile ilgilenmezler. }\end{array}$ \\
\hline $\begin{array}{l}\text { Karmaşa } \\
\text { Yaşayanlar }\end{array}$ & $\begin{array}{l}\text { Pek çok marka ve mağaza arasında seçim yapmakta zorlanan tüketici tarzıdır. Fazla bilgiden kaynaklı } \\
\text { olarak alışverişlerinde kararsılık yaşamaları muhtemeldir. }\end{array}$ \\
\hline Rutin Alışveriş & $\begin{array}{l}\text { Favori marka ve mağazalara sahip olmaları ve bunları seçme alışkanlıkları edinmeleri muhtemel } \\
\text { tüketici tarzıdır. Alışıllmış davranış tüketicinin karar vermesinin iyi bilinen bir yönüdür, bu tarza sahip } \\
\text { olan tüketicilerin alıştıkları markaları kolayca değiştirmeleri beklenmez. }\end{array}$ \\
\hline Moda Odaklılar & $\begin{array}{l}\text { Yenilik ve modaya düşkün tüketici grubunu tanımlamaktadır. Tarzları takip ederler ve stil sahibi } \\
\text { olmak onlar için önemlidir. Yeni olan ve modaya uygun ürünleri tercih etmeleri beklenir. }\end{array}$ \\
\hline
\end{tabular}

Kaynak: Sproles ve Kendall, 1986

Söz konusu sınıflamaların ölçümünün sağlanması için birçok test gerçekleştirilmiştir. Hafstrom vd. (1992) Kore, Shim (1996) Amerika, Dursun (2010) Türkiye'deki örneklemlerle envanterin testini sağlamıştır. Tüketici satın alma tarzlarına yönelik ölçeğin uyarlanmasının Dursun vd. (2010) tarafından kullanılması sonucunda Türk tüketiciler üzerinde etkili bir gruplandırma aracı olarak kullanılabileceği ortaya koyulmuştur. Ceylan (2013) tarafından Tüketici Tipleri Envanterinin Türk kültüründeki geçerliliğinin araştırılmasına yönelik yapılan çalışmada ise orijinal ölçek ile beş boyutun benzer özellikte olduğu saptanmıștır. Fiyat odaklılık, dürtüsel alışveriș ve rutin alıșveriş boyutlarının Türk kültürüne uyarlanan ölçekte faktörleşmediği belirtilmiştir. Bununla birlikte "fiyat odaklılar" boyutunun diğer kültürlere uyarlanan ölçeklerde ya hiç oluşmadığı ya da düşük güvenilirlik değerleri elde edildiği, bu sebeple "fiyat odaklılar" boyutuna ait maddelerdeki ifadelerin yeniden düzenlenmesiyle ölçeğin gücünün artırılabileceği ifade edilmiştir. Tüketici envanterini kullanarak yapılan çalışmalarda tüketicilerin bazı davranış kalıplarından uzaklaşabildiği sonucuna ulaşılmıştır. Yüksekbilgili (2016), Engizek ve Şekerkaya'nın (2016) çalışmalarında, tüketicilerin satın alma eğilimlerine göre farklı özelliklere sahip olabilecekleri görülmüştür. Yani tüketicilerin tam olarak sekiz farklı satın alma tarzı göstermeyebileceklerini ifade etmek mümkündür. Bununla birlikte, bu araştırma, alanyazında tüketicileri tanımlamada kullanılan altı satın alma tarzı üzerinden yürütülmektedir. Araştırmada kullanılan satın alma tarzları; mükemmeliyetçiler, marka odaklılar, eğlence odaklılar, fiyat odaklılar, dürtüsel alışveriş ve karmaşa yaşayanlar şeklindedir. 


\subsection{Sosyal Medya Reklamları}

Sosyal medya; kullanıcıların bilgi, fikir, ilgi alanı ve görüşlerini diğer kullanıcılarla internet iletişimi temelli ağlarla paylaştıkları platformlar olarak tanımlanmaktadır. Katılım sağlama, bağlantılı olma, topluluk oluşturma, karşılıklı iletişim ve açıklık sosyal medya ağlarının sahip olduğu özellikler olarak öne çıkmaktadır. Kullanıcıların site içeriğini oluşturmaya yetkin olmadıkları ve sadece web sitelerinde yer alan bilgilere erişebildikleri Web 1.0 tabanı web sitelerinin içeriğinin geleneksel medyada olduğu gibi seçilmiş bir grup tarafindan oluşturulmasına olanak sağlıyordu. Web 1.0 tabanının devamı niteliğindeki Web 2.0 ise tüm cihazlara bağlanabilme özelliği barındıran bir ağ platformudur. Web 2.0'ın kullanılmaya başlanmasıyla, kendisine iletini okuyan veya izleyen kullanıcıların yerini internetten içerik edinen ve yükleyen kullanıcılar almıştır (Ada vd., 2013; Caladine, 2008). "Katılımcı web" teriminin ortaya çıkmasıyla internet kullanıcıları bilgiyi sadece tüketen değil hem bilgi üreten hem de bilgi tüketen şekline dönüşmüştür.

İnternetin ve sosyal medya kullanımının yaygınlaşmasıyla birlikte pazarlama alanında da yapılan faaliyetlerde yenilikler kendini göstermiştir. Pazarlama çabalarında geleneksel medya ile birlikte sosyal medya kanalları da etkin birer araç olarak yerini almıştır. Sosyal medya reklamları pazarlama çalışmalarında işletmelerin farkındalık oluşturacakları ve marka algısını olumlu yönde artıracakları yeni platformlar olmaktadır (Wei vd., 2010). Battallar ve Cömert'e (2015) göre işletmelerin sosyal medya aracılığıyla yürüttükleri pazarlama faaliyetlerinin işletmelere sağladığı birtakım yararlar bulunmaktadır. Bunlar; tüketicilerle iyi ilişkiler geliştirme, hedef pazara daha kolay erişim sağlama, markalama, firsat doğduğu anda satış yapabilme ve daha az para harcayarak reklam yapabilmektir. Bununla birlikte sosyal medya reklamları kısa sürede etkili olabilmektedir. Bunda reklam veren markanın dışında diğer kullanıcıların da reklamı yapılan ürün hakkında yaptıkları yorum, beğeni vb. paylaşımlarının referans olma özelliği bulunmaktadır. Kişilerin tanıdıklarının yönlendirmeleri sonucunda sosyal medya reklamları daha geniş kitlelere yayılabilmektedir. Örneğin, kişilerin sosyal medyada beğendikleri bir paylaşımı ağındaki diğer insanlarla paylaşması söz konusu yönlendirmeyi ifade etmede kullanılabilir.

Tüketicilerin sosyal medyayı kullanma oranlarının giderek arttığı günümüz dünyasında, sosyal medya reklamlarının tüketicilerin satın alma kararlarını etkileyen önemli uygulamalar haline geldiğini ifade etmek mümkündür. Sosyal medya kullanımlarında görülen yoğun artışla beraber firmaların da sosyal medya reklamları vasıtasıyla tüketici karar süreçlerini etkilemeye çalıştığı bilinmektedir. Sosyal medyanın artarak gelişim gösteren yapısı ve tüketicilerin satın alma kararlarını verirken sosyal medyayı kullanma yoğunluklarının artış göstermesi, tüketici davranışlarında meydana gelen önemli bir değişimin de açık bir göstergesi olmaktadır. Günümüz dünyasında sosyal medya, işletmeler için yoğun bir rekabet ortamı halini almaktadır. Önemini ve değerini günden güne artıran sosyal medya reklamları ve dolayısıyla sosyal medya pazarlaması, günümüzde firmalar açısından uygulanması gerekli hale gelen ciddi faaliyetler olmaktadır (Aksoy \& Gür, 2018).

Sosyal medya reklamlarının tüketicilerin satın alma tutum ve niyetlerini olumlu yönde etkilediği belirtilen "bilgi sağlama" rolü, ürünlerin faydalarını satın alma aşamasında hemen ortaya koyması açısından önemli bir yere sahip olmaktadır (İslamoğlu, 2009). Aynı zamanda bilgi sağlama, ödeme şartlarını bildirmek, ürünün kullanım alanlarını belirtmek gibi ürünle ilgili birçok bilgiyi tüketiciye sunmaktadır (Ducoffe, 1996). İnternete kolay erişim sağlanması ve sosyal medya uygulamaların yaygınlaşması sonucunda tüketicilerin bilgi seviyesi her geçen gün artmakta, ihtiyaç ve isteklerini belirleme ve ifade etme şekilleri de değişime uğramaktadır.

Ĕglence sunma, sosyal medya reklamlarının daha etkin ve verimli sonuçlar ortaya koymasını sağlayan diğer bir özelliktir. Eğlence sunma, müşteriler için zevk, hayal kurmak, estetik sunabilme olarak açıklanmaktadır. Tüketiciler, sosyal medya reklamların da eğlenceli olmasını beklemektedirler (Akkaya vd., 2018). Eğlenceli reklamların, tüketiciler tarafından daha olumlu şekilde algılanacağı ve reklamın değerini arttıracağı düşünülmektedir (Amjad vd., 2015).

Sosyal medya reklamlarının "güvenilirliği”, reklamların doğruluğunu ve inanılırlığını temsil etmesi açısından satın alma niyeti üzerinde önemli bir yere sahip olmaktadır. MacKenzie ve Lutz (1989), tüketicilerin genel olarak reklamlarla ilgili güvenilirlik algılarının, satın alma kararlarında önemli bir etkiye sahip olduğunu ileri sürmektedirler. 
Satın alma niyetine etki edebilen diğer bir sosyal medya reklam özelliği "ekonomiye katkı" olarak bilinmektedir. Günümüzde reklamlar, işletmelerin varlıklarını sürdürebilmek için reklamlardan faydalanmaktadırlar. İşletmelerin ve dolayısıyla ekonomilerin canlanması ve rekabet ortamının geliştirilerek çeşitli ekonomik katkıların piyasaya sunulması açısından sosyal medya reklamları önemli bir rol üstlenmektedir (Aksoy \& Gür, 2018; Ting vd., 2015).

\subsection{Mobil Alışveriş Niyeti}

Tüketicilerin, belli bir zaman aralığı içerisinde, belli bir marka veya üründen belli miktarlarda satın almayı planlaması durumu, satın alma niyeti olarak tanımlanmaktadır (Gökalan, 2009). Satın alma niyetinin temelini, tüketicilerin belli bir mal ya da hizmete olan ihtiyaçlarını fark ettikleri için ilgili mal ve hizmetleri satın alma davranışına yönelmeleri yatmaktadır. Başka bir ifadeyle satın alma niyetinin önemli bir kısmı, tüketicilerin bir ürünün satın alınmaya değer olduğunu keşfedip satın almayı gerçekleştirmesi ile oluşmaktadır (Madahi \& Sukati 2012). Satın alma niyeti hakkında yapılan bu tanımlamalar göz önüne alındığında, mal ve hizmet çeşitliliğinin ve geniş ürün yelpazesinin bulunduğu günümüz pazarlarında, mal ve hizmetlerin tüketiciler tarafindan fark edilip keşfedilmesi önemli bir pazarlama sorunu halini almaktadır. Problemin çözümümde, tüketicilerin firma ürünlerini keşfedebilmesi için sosyal medya reklamlarından faydalanmasını ön plana çıkarmaktadır. Denghani ve Tumer (2015) tarafından Facebook üzerinde yapılan bir çalışmada, reklam faaliyetlerinin tüketici satın alma niyeti üzerindeki etkileri araştırılmaktadır. Çalışma sonuçlarına göre tüketicilerin sosyal medya reklamlarına yönelik algılarının satın alma niyeti üzerinde önemli bir etkiye sahip olduğu saptanmıştır. Sosyal medya uygulamalarının güvenilir olarak algılanması, tüketicilerin satın alma niyetlerini olumlu yönde etkileyebilmektedir (Özçiftçi, 2020). Özellikle sosyal medyada ticari faaliyetlerde sosyal medyanın güvenilir olması ve faydalı olması ile tüketicilerin satın alma niyetleri arasında olumlu ilişkiler bulunmaktadır (Pınar vd., 2019). Teknolojik gelişmelerin hızlı olduğu ve dolayısıyla tüketicilerin mobil cihazlar vasıtasıyla satın alma eğilimlerinin yükseldiği günümüz dünyasında, mobil alışverişin öneminin de giderek arttığı görülmektedir. Tüketicilerin, gelecekte belli bir mal veya hizmeti mobil cihazlardan satın almayı planlaması ve satın alma isteği göstermesi, mobil alışveriş niyetinin bir tanımlayıcısı olmaktadır. Mal ve hizmet çeşitliliğinin ve mobil alışverişin artı̧̧ göstermesi, çeşitli sosyal medya reklamları vasıtasıyla mobil alışveriş niyetini etkileyerek tüketicileri satın alma davranışına yöneltme noktasında firmalara önemli firsatlar sunmaktadır.

\subsection{Kavramlar Arası İlişkiler ve Hipotez Geliştirme}

\subsubsection{Tüketicilerin satın alma tarzları ile mobil satın alma arasındaki ilișkiler}

Leng ve Botelho (2010) tarafindan ulusal kültür açısından karar verme tarzlarının tespit edilmesi amaçlanmıştır. Araştırma, Japonya, Amerika ve Brezilya'dan toplam 319 katılımcı ile gerçekleştirilmiştir. Araştırma sonucunda kalite bilinci, marka bilinci, yenilikçilik, eğlendirme, fiyat bilinci, dürtüsellik, dikkatsiz satın alma ve marka sadakati boyutlarının kültür açısından farklılaştığı sonucuna ulaşılmıştır. Ayrıca, kültürün tüketici karar verme stillerinde belirleyici faktörlerden birisi olduğu ifade edilmiştir. Yang ve Kim (2012) tarafindan yapılan araştırmanın amacı, mobil cihazlar aracılığ ile alışveriş yapan tüketicilerin mobil alışveriş motivasyonlarına etki eden faktörlerin belirlenmesidir. Araştırmada veri toplama tekniği olarak çevrimiçi anket formu kullanılmıştır. Araştırma kapsamında 400 örnekleme ulaşılmıştır. Araştırmanın örneklemi 19-30 yaş aralığındaki çoğunluktan oluşmaktadır. Tüketicilerin özelliklerinin belirlenmesinde çoklu ayırma analizi kullanılmıştır. Araştırma neticesinde eğlence, memnuniyet, macera arayışına sahip kişilerin mobil cihazlarla alışveriş yapmaya daha çok motive oldukları tespit edilmiştir. Mehta ve Dixit (2016) tarafindan yapılan araştırmada, gelişmiş ve gelişmekte olan pazarlarda tüketici karar verme stilleri incelenmiş̧ir. Araştırmada 558 Hindistanlı ve 185 Alman öğrenci yer almıştır. Katılımcılardan anket aracılığı ile veri toplanmıştır. Araştırma sonucunda tüketicilerin satın almada karar verme tarzlarının gelişmiş ülkelerde daha uygun bir kullanım alanına sahip olduğu sonucuna ulaşılmıştır. Karar verme tarzlarının Hindistanlı öğrencilerde mükemmeliyetçilik, hedonizm, dikkatsiz alışveriş, fiyat değer bilinci, alışkanlık-marka sadakati, fiyat/kalite eşitliği konularını açıklamada anlamlı olduğu, marka bilinci ve zaman bilinci konularında ise anlamsız olduğu görülmüştür. Alman öğrencilerde ise çeşitlilik arayışı, marka sadakati ve dikkatsiz alışveriş yapma eğilimlerinin açıklanma düzeyinin anlamsız olduğu görülmüştür. Eriksson vd. (2017) tüketicilerin satın alma stillerine bağlı olarak mobil 
cihazlardan giyim alışverişleri yapma niyetlerinin incelenmesini amaçlamışlardır. Araştırmanın örneklemi 77 erkek ve 67 kadın mobil cihaz kullanıcısından oluşmaktadır. Araştırma sonucunda, marka bilinci, moda bilinci, dürtüsellik ve eğlendirici alışveriş davranışlarının mobil satın alma ve mobil satın alma sıklığı arasında anlamlı ilişkiler bulunduğu tespit edilmiştir. Sarkar vd. (2019) tarafından yapılan araştırmada, mobil alışveriş uygulamalarını kullanan tüketicilerin satın alma kararını nasıl verdikleri tespit edilmiştir. Araştırmada ayrıca tüketici karar verme tarzı ölçeğinin doğrulanması amaçlanmaktadır. Araştırma kapsamında yaygın olarak bilinen 5 mobil alışveriş uygulamasını kullanan 428 tüketiciden çevrimiçi anket ile veri toplamıştır. Araştırma sonucunda tüketicilerin mobil alışveriş sitesi seçiminde ve alışveriş yapma niyetlerinde tüketici stillerinin etkili olduğu sonucuna ulaşılmıştır. Çalışma bulgularına göre, ölçeğin tüketicilerin karar verme tarzlarını ölçmeye uygun olduğu sonucuna ulaşılmıştır. Alanyazında yer alan araştırma sonuçları, tüketicilerin satın alma tarzlarının onların mobil cihazlarını kullanarak satın alma niyetleri üzerinde etkili olduğunu göstermektedir. Alanyazında yer alan bulgulardan yola çıkarak oluşturulan hipotez aşağıda yer almaktadır;

\section{$\boldsymbol{H}_{1}$ : Tüketicilerin satın alma tarzlarının mobil alışveriş niyeti üzerinde anlamlı bir etkisi vardır.}

Chong (2013) tarafindan tüketicilerin mobil alışveriş niyetlerinde etkili olan faktörlerin tespit edilmesi amaçlanmıştır. Araştırmada 376 birey katılımcı olarak yer almıştır. Araştırma sonucunda zevk, güven, maliyet ve sosyal çevrenin, tüketicilerin mobil cihazlardan alışveriş yapmasında önemli faktörler olduğu tespit edilmiştir. Ayrıca tüketicilerin hizmet çeşitliliği, kullanışlılık, güven, sosyal ağları ve zevk arayışları mobil alışveriş yapmada en önemli faktörler olarak yorumlanmıştır. Azeem ve Haq (2012) tarafından tüketicilerin sosyal medya reklamlarına ilişkin algılarının araştırıldığ çalışmada, sosyal medya reklamlarının ekonomiye olan katkıları faktörü, tüketicilerin sosyal medya reklamlarına ilişkin tutumlarını en çok etkileme potansiyeline sahip olan faktör olarak belirtilmektedir. Kayapınar vd. (2017) tarafından yapılan araştırmada 876 katılımcı yer almış ve araştırmanın amacı, tüketicilerin sosyal medya reklamları ile ilgili algılarının e-sadakate etkisinde markaya yönelik tutumun rolünün belirlenmesi olarak belirlenmiştir. Araştırma sonuçlarına göre sosyal medya reklamlarının eğlence ve bilgi sunma özelliklerinin tüketicilerin markaya olumlu yaklaşımlar geliştirmesini sağladığı ve markaya e-sadakat oluşturmada önemli olduğu sonucuna ulaşılmıştır. Varkaris ve Neuhofer (2017) tarafından yapılan çalışmada nitel teknikler kullanılmıştır. Araştırma bulgularına göre, sosyal medyanın tüketicilerin karar vermesi, hizmet hakkında bilgi toplaması ve satın alma açısından yönlendirdiği sonuçlarına ulaşılmıştır. Anlık bilgi alma, güvenilirlik, avantajlı olma konuları açısından sosyal medyadan karar verme sürecinin işletildiği tespit edilmiştir. Alanyazında yer alan farklı çalışma sonuçlarının ortak bulgusu; tüketicilerin satın alma tarzlarının, sosyal medya reklamlarının içeriği ve özelliklerini anlamlandırmada önemli bir faktör olduğu şeklindedir. Elde edilen bu çıkarımdan hareketle oluşturulan hipotez şu şekildedir;

$\boldsymbol{H}_{2}$ : Tüketicilerin satın alma tarzlarının sosyal medya reklamlarının özelliklerinin algılanması üzerinde anlamlı bir etkisi vardır.

\subsubsection{Sosyal medya reklamları ile mobil satın alma arasındaki ilişkiler}

Köker vd. (2018) tarafından yapılan araştırmada, 584 katılımcı yer almıştır. Araştırmanın amac1, tüketicilerin internette geçirdikleri sürenin satın alma niyetine etkisinin tespit edilmesidir. Araştırma sonuçlarına göre tüketicilerin sosyal medyada geçirdikleri zaman, tüketicilerin çevrimiçi satın alma eğilimlerini farklılaştırmaktadır. Söyleyici ve Çetinkaya Bozkurt (2017) tarafından yapılan araştırmada 425 sosyal medya kullanıcısı katılımeı yer almıştır. Araştırmanın amacı sosyal medya ve kullanıcıların davranışları arasındaki ilişkinin tespit edilmesi olarak belirlenmiştir. Araştırma sonuçlarına göre, katılımcıların sosyal medya reklamlarına ve tüketici davranışlarına özgü olarak demografik özellikler açısından anlamlı farklılıkların meydana geldiği görülmüsstür. Aksoy ve Gür (2018) tarafından yapılan araştırmada 382 katılımcı yer almıştır. Araştırmada üniversite öğrencilerinin sosyal medya reklamlarının algılama biçimlerinin satın alma niyetine ne şekilde etki ettiğinin tespit edilmesi amaçlanmıştır. Araştırma sonucunda, sosyal medya reklamlarının eğlendirici olmasının, güvenilir içeriğe sahip olmasının ve ekonomik olarak katkı sunmasının satın alma niyetini arttırdığı sonucuna ulaşılmıştır. Gao vd. (2015) tarafindan 462 katılımcı ile yapılan araştırmada, mobil alışverişe devam etmeyi sağlayan faktörler tespit edilmeye çalışılmıştır. Araştırmada bilgi kalitesi, gizlilik, 
güvenlik, firmaya güven, akış, tatmin, mobil alışverişe devam niyeti değişkenleri kullanılmıştır. Kişiler, markadan sürekli güncel ve farklı içeriklerde ürün bilgisi beklemekte olduğu, bu durumda alışverişe devam etme niyetinin arttığ 1 sonucuna ulaşılmıştır. İçeriklerin ilgi çekici olarak sunulması, alışveriş niyetinin devamlılığı konusunda önemlidir. Xie ve Lee (2015) tarafından sosyal medya faaliyetlerinin tüketicilerin markalı ürünleri satın alma niyetlerine etkisi tespit edilmeye çalışılmıştır. Araştırmada bir markanın sosyal medya sayfasındaki mesajlar incelenmiştir. Araştırma sonuçlarına göre, sosyal medyadaki faaliyetlerin tüketicilerin satın almasına olumlu etkileri olduğu görülmektedir. Bunun yanında, çevrimiçi promosyonların mağazandan satın almaya ise etkisinin olmadığı sonucuna ulaşılmıştır. Yukarıda yer alan çalışma sonuçları genel olarak incelendiğinde, tüketicilerin sosyal medya reklamları ile ilgili algılamalarının ve tutumlarının, onların mobil cihazlarını kullanarak alışveriş yapma eğilimlerini etkilediği sonucuna ulaşılmaktadır. Söz konusu çıkarım sonucunda oluşturulan hipotez şu şekildedir;

$\boldsymbol{H}_{3}$ : Sosyal medya reklamlarının özelliklerinin algılanma şeklinin mobil alışveriş niyeti üzerinde anlamlı bir etkisi vardır.

\subsubsection{Tüketicilerin satın alma tarzları ile mobil satın alma arasındaki ilişkilerde sosyal medya reklamlarının aracılık rolü}

Sosyal medya reklamları tüketiciler için doğrudan satın almaya dönüşmese bile, tüketiciler sosyal medya reklamlarını takip edebilmekte ve satın alma işlemi öncesinde bilgi sağlama unsuru olarak kullanabilmektedirler (Ulama \& Koç, 2019). Ayrıca tüketicilerin farklı satın alma stillerine sahip olması, tüketicilerin satın alma niyetleri üzerinde etkili olabilmektedir. Tüketicilerin bilgi, mal hizmet kalitesi, güven arayışı, gizlilik gibi duyarlılıkları tüketicilerin satın alma davranışlarında belirleyici olabilmektedir (Gao vd., 2015). Genç kuşaklarda teknoloji kullanımının yoğun olmasına bağlı olarak, genç tüketicilerin sosyal medya reklamlarına ilgilerinin yüksek olduğu, reklamları takip ederek bilgi alma neticesinde satın alma eğiliminde olabildikleri görülmektedir (Şener \& Yücel, 2020). Tüketicilerin satın alma tarzlarının mobil satın alma eğilimleri üzerinde önemli etkileri olduğu bilinmektedir. Tüketicilerin mükemmeliyetçi, moda eğilimli, fiyat odaklı olmaları, tüketicilerin mobil cihazları üzerinden satın alma işlemlerini etkilemektedir. Örneğin, tüketicilerin mükemmeliyetçi yapıda olmaları mobil satın alma için kullanılan uygulamaların risk, eğlenceli oluşu ve kullanışlılığı hakkındaki hassasiyeti arttırmaktadır (Sarkar vd., 2020). Tüketicilerin satın alma tarzlarının mobil cihazlardan satın alma niyetine etkisinde sosyal medya reklamlarının aracılık rolünü inceleyen net bir çalışmaya rastlanılamamıştır. Bu yüzden aracılık ilişkisi hakkında alanyazın kanıtları kısıtlı olarak sunulmaktadır. Bununla birlikte yukarıda yer alan çalışmaların sonuçları birlikte düşünüldüğünde, tüketicilerin satın alma tarzlarının mobil cihazlardan satın alma niyeti ile ilişkisi, tüketicilerin satın alma tarzlarının sosyal medya reklamları ile ilişkisi ve son olarak sosyal medya reklamlarının tüketicilerin mobil cihazlardan satın alma niyetlerine etkisi ile olan ilişkisinden hareketle hipotez oluşturulmaktadır. Sosyal medya reklamlarının aracılık rolü ile ilgili hipotez şu şekildedir;

$\boldsymbol{H}_{4}$ : Tüketicilerin satın alma tarzlarının mobil satın almaya etkisinde sosyal medya reklamlarının aracılık rolü bulunmaktadır.

\section{ARAŞTIRMANIN YÖNTEMI}

Araştırmanın bu kısmında, araştırma sürecinin nasıl gerçekleştirildiğini gösterebilmek için araştırmanın hangi amaçla gerçekleştirildiği ve elde edilecek sonuçların neden önem arz ettiği, araştırmanın amacına uygun olarak belirlenen araştırma örneklemi, örnekleme süreci, örneklemden toplama için kullanılan ölçüm araçları ve araştırmanın kavramsal modeli hakkında bilgiler sunulmaktadır.

\subsection{Araştırmanın Amacı ve Önemi}

Çevrimiçi alı̧̧veriş, internet tabanlı olarak mal veya hizmet satın alma süreci şeklinde tanımlanmaktadır (Özgüven, 2011). Çevrimiçi alışveriş geçmiş dönemde bilgisayarlar üzerinden gerçekleştirilmekteydi. Mobil cihazların internet ile buluşması ve pek çok özelliği barındıran mobil uygulamaların kullanıcılara sunmasıyla mobil cihazlar üzerinden de çevrimiçi alışveriş yapılmaya başlanmıştır. Mobil alışveriş olarak tanımlanan bu alışveriş türü akıllı telefonlar ve tablet bilgisayarlar aracılığıyla perakendecilerden mal veya hizmet satın almayı ve ödeme gerçekleştirebilmeyi olanaklı 
kılan yeni ve özel bir kanaldır. Mal veya hizmet ile ilgili bilgi arama, ödeme yapma ve teslimat konularında çevrimiçi alışverişe benzerlik gösterse de mobil alışveriş, sabit bilgisayarlar üzerinden alışverişin sağlayamadığı mekândan bağımsız olarak alışveriş yapabilme özelliği ile yepyeni bir deneyim sunmaktadır. Pantano ve Priporas'a (2016) göre bilişsel açıdan tüketiciler için daha uygun olan mobil alışveriş deneyimi yaşama imkânı, çevrimiçi alışveriş yerine mobil alışverişi tercih etmeyi sağlayabilir. TÜSİAD (2019) tarafından yayınlanan "E-Ticaretin Gelişimi, Sınırların Aşsılması ve Yeni Normlar: 2019" raporuna göre Türkiye'de, özellikle çevrimiçi perakende alanında, tüketici ziyaretlerinin $\% 70^{`}$ ten fazlasının mobil kanallar üzerinden gerçekleşmesi, firmaların elde ettiği gelirlerin \%60'tan fazlasının mobil alışveriş ile sağlanması, mobil alışveriş için özel çalışmaların yapılması gerekliliğini ortaya koymaktadır. Sosyal medya platformlarının ve çevrimiçi alışveriş kanallarının tek bir mobil cihazda kullanılabilir olması, uygulamalar arasındaki etkileşimi de arttırmaktadır. Tüketicilerin sosyal medya kullanımları esnasında gördükleri mal ve hizmetleri anlık olarak mobil uygulamalar ve mobil kanallar üzerinden satın almasının kolay olması, mobil satın alma faaliyetleri üzerinde daha çok durulması gereken bir alan haline getirmektedir. Tüketicilerin satın alma tarzlarındaki farklılıklar ve sosyal medya reklamlarının son yıllarda yoğun kullanımı birlikte düşünüldüğünde mobil satın alma işlemini gerçekleştirmeyi etkileyen unsurların neler olduğunun tespit edilmesi, araştırmacılar, tüketiciler ve diğer paydaşlar açısından önemli bir sorunsalı ortaya çıkarmaktadır.

Yukarıda ifade edilen bilgiler ışı ğında araştırmanın sorusu "Tüketicilerin mobil satın alma işleminde etkili olan faktörler nelerdir?" şeklinde oluşturulmuştur. Mobil cihazlarda yaygın biçimde kullanılan sosyal medya reklamlarının tüketici tarzlarına göre mobil alışveriş niyetine farklı şekilde etki edebileceği düşüncesiyle araştırmanın amacı "tüketici tarzlarının mobil alışveriş yapma niyetine etkisinde sosyal medya reklamlarının aracı rolünün tespit edilmesi" olarak belirlenmiştir. Araştırma sonucunda elde edilecek bulgular tüketicilerin mobil alışveriş deneyimini tercih etmelerinde tüketici özelliklerinin etkisi ve sosyal medya reklamlarının tüketici tarzlarına göre mobil alışveriş yapma niyetindeki aracı etkisinin belirlenebilmesi için açısından önem arz etmektedir. Elde edilecek sonuçlar, tüketici tarzına uygun reklamlar oluşturma, satın alma sürecini daha kaliteli hale getirme açısından önem taşımaktadır. Ayrıca elde edilecek sonuçlar, daha önce incelenmemiş bir sorun açısında bulgular oluşturarak, araştırmacılara kısıtlı da olsa bir yol gösterecektir.

\subsection{Araştırma Evreni, Örneklemi ve Örnekleme Yöntemi}

Araştırma evreni, mobil cihaza sahip, sosyal medya hesabı kullanan ve mobil alışverişten haberdar olan 18 yaşından büyük tüketicilerden oluşturmaktadır. Söz konusu evrene ulaşmadaki kısıtlar göz önüne alınarak araştırma evrenini yansıtacak şekilde örneklem seçimi yapılmıştır. Örnekleme yöntemi olarak kolayda örnekleme metodu tercih edilmiştir. Kolayda örnekleme, evrenin içinden seçilecek örneklemin araştırmacı tarafından belirlendiği olasılıklı olmayan örnekleme yöntemidir. Bu yöntemde veriler, evrenden kolay, ekonomik ve hılı biçimde toplanır. Kullanım kolaylığının yanı sıra örneklemin ana kütleyi temsil yeteneğinin düşük olması ve ana kütleye ilişkin bir genelleme yapılmasını zorlaştırması kolayda örneklem yönteminin olumsuz yönleridir (Koç Başaran, 2017). Araştırmanın belirli bir ürün, marka veya işletmeye yönelik olmamasından dolayı kolayda örnekleme yönteminin uygun olacağı düşünülmüştür. Anket formunun katılımcılara gönderilmesinden önce araştırmanın etik değerlere uygun biçimde yürütüldüğünü gösteren Etik Kurul Onayı 11.05.2020 tarihinde Beykent Üniversitesinden alınmıştır. Oluşturulan çevrimiçi anket formu 14.05.2020 ile 23.05.2020 tarihleri arasında katılımcılara ulaştırılmıştır. Belirlenen tarihler arasında 1162 tüketici çevrimiçi ankete katılım sağlamıştır. Anket formunun araştırmada kullanılabilecek özellikte olup olmadığının belirlenmesi için yapılan kontrol sonucunda, anketlerin tamamının uygun doldurulduğu tespit edilmiştir. Böylece anketlerden hiç birisi araştırma kapsamı dışında bırakılmamıştır.

\subsection{Araştırmanın Veri Toplama Araçları ve Veri Toplama Süreci}

Mobil akıllı cihaza sahip ve sosyal medya kullanıcı hesabı bulanan tüketicilerin katılımı ile gerçekleştirilen araştırmanın verilerinin toplanması için çevrimiçi anket formu kullanılmıştır. Anket formunun ilk kısmında, Sproles ve Kendall (1986) tarafından oluşturulan Tüketici Tarzları Envanteri (TTE) ölçeğinin Alnıaçık (2012) tarafindan Türkçe’ye uyarlanmış hali kullanılmıştır. Orijinal ölçekte 
bulunan sekiz boyut Türkçe'ye uyarlanan ölçekte yedi boyut şeklinde yer almaktadır. Bu araştırmada kullanılan ölçeğin dışında Türkçe literatürde yer alan Tüketici Tarzları Envanteri ölçekleri de incelenmiş olup Dursun vd. (2013) tarafindan yapılan araştırmada dokuz farklı boyutun oluştuğu sonucuna ulaşılmıştır. Araştırmada TTE ölçeği orijinal ölçekte yer alan sekiz boyutundan "moda odaklılık" ve "rutin alışveriş" boyutlarının yapılan ön testte iki maddeli faktör oluşturması nedeniyle araştırma kapsamından çıkarılmıştır. Hair vd.'ne (2014) göre iki maddeli ölçüm araçlarının güvenilirlik geçerliliğinin test edilmesinin zor olmasına bağlı olarak söz konusu boyutlar araştırmada kullanılmamıştır. TTE ölçeği 29 maddeden oluşmaktadır. Ölçekte yer alan maddeler için cevaplar 5'li Likert tipi ölçümle sağlanmıştır. Anket formunun ikinci bölümünde Aksoy ve Gür (2018) tarafından oluşturan Sosyal Medya Reklam Algısı Ölçeği ile Satın Alma Niyeti Ölçeğinin araştırmaya uyarlanmış hali kullanılmıştır. Sosyal medya reklam algısı ölçeği 13 maddeden oluşmuştur. Ölçekte yer alan maddeler için cevaplar 5'li Likert tipi ölçümle sağlanmıştır. Satın alma niyeti ölçeğinin mobil alışveriş niyetine uyarlanmış ölçeği 4 maddeden oluşmaktadır. Ölçekte bulunan maddelere cevaplar 5'li Likert tipi ölçümle sağlanmıştır. Anket formunun son bölümünde ise tüketicilerin tanımlayıcı özelliklerine ait sorular (cinsiyet, yaş, medeni hal, eğitim düzeyi, kişisel gelir, sosyal medya reklamlarına karşı tutum vb.) bulunmaktadır.

\subsection{Araştırmanın Kavramsal Modeli}

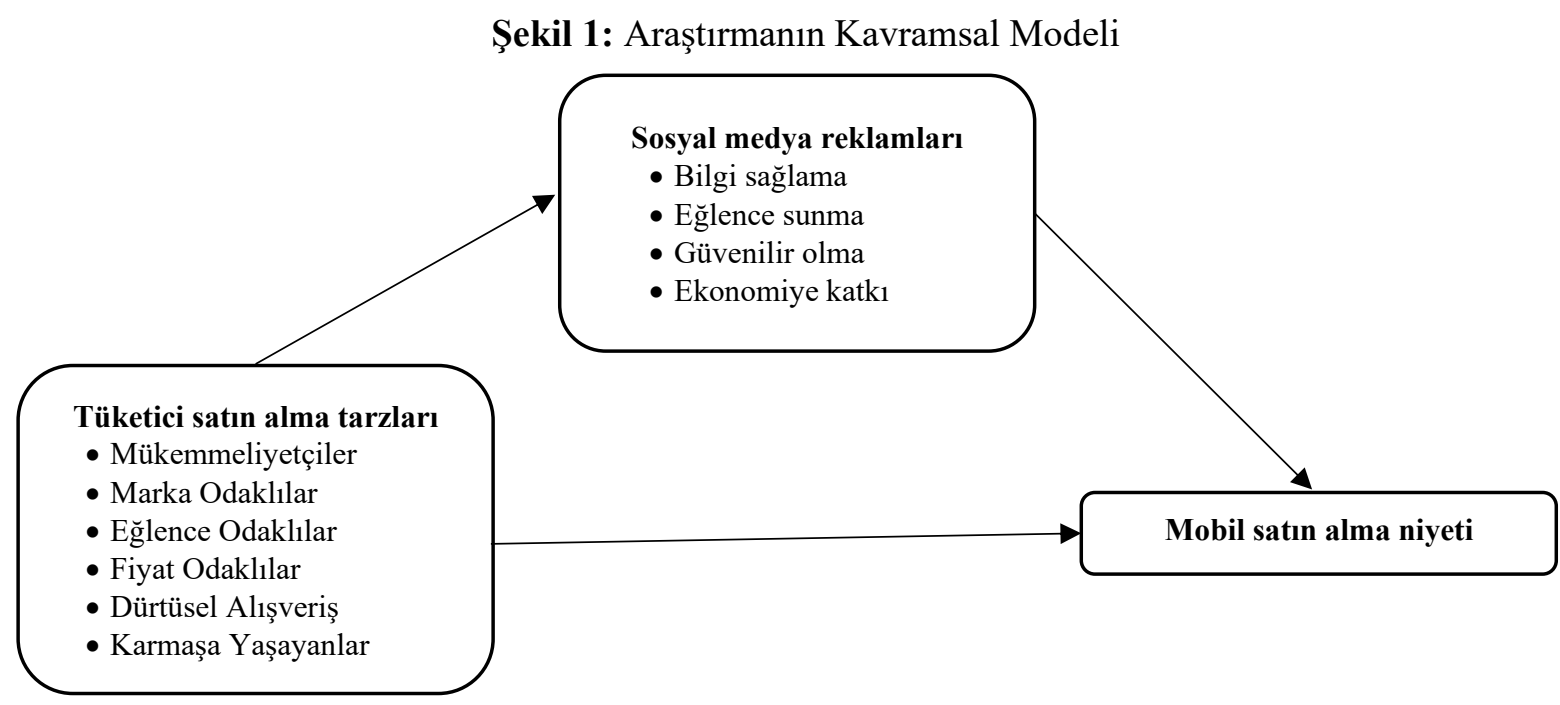

Şekil 1'de yer alan kavramsal modelin oluşturulmasında alanyazında yer alan çalışmalardan faydalanılmıştır. Modelde tüketicilerin satın alma tarzı ve alt boyutları bağımsız değişkeni (x), sosyal medya reklamları ve alt boyutları aracı değişkeni (m), mobil satın alma niyeti ise bağımlı değişkeni (y) temsil etmektedir.

\section{ARASSTIRMANIN BULGULARI VE YORUMLARI}

Araştırmanın bu kısmında, araştırmanın amacı esas alınarak araştırma verilerinin analizi ve bulguların yorumlanması gerçekleştirilmektedir. Öncelikle, SPSS 25 paket programı aracılığ 1 ile araştırmada kullanılan ölçüm araçlarının geçerlilik ve güvenirlik analizleri gerçekleştirilmektedir. Daha sonra araştırmanın örnekleminde yer alan tüketicilerin özelliklerini belirten tanımlayıcı istatistikler sunulmaktadır. Değişkenler arasındaki ilişkilerin tespit edilebilmesi için korelasyon analizi gerçekleştirilmektedir. Son olarak değişkenler arasındaki ilişkilerin anlamlılığına bağlı olarak SPSS Process 2.16 makrosu ile aracılık analizleri gerçekleştirilmektedir. Aracılık analizlerinin gerçekleştirilmesinde Hayes (2018) tarafından oluşturulan 4 numaralı model kullanılmaktadır. Hayes tarafından sunulan 4 numaralı model, araştırmanın kavramsal modelini (Şekil 1); bağımlı değişken, bağımsız değişken ve aracı değişken olacak şekilde tam anlamı ile karşılamaktadır. 4 numaralı model kullanıldığında, tüketicilerin satın alma tarzları araştırmanın bağımsız değişkeni, sosyal medya reklamları aracı değişkeni, mobil satın alma niyeti ise bağımlı değişkeni temsil etmekte ve söz konusu model araştırmanın amacının sağlıklı şekilde test edilmesine olanak sağlamaktadır. 


\subsection{Faktör ve Güvenilirlik Analizi Sonuçları}

Araştırma kapsamında kullanılan ölçüm araçlarının uygunluğunun test edilebilmesi için faktör analizi ve güvenilirlik analizi yapılmaktadır. Faktör analizi sonucunda elde edilen Kaiser-Meyer-Olkin (KMO) örneklem yeterliliği ölçümü, Bartlett's küresellik testi sonucu açıklanan toplam varyans değeri ile güvenilirlik analizi sonucunda elde edilen güvenilirlik katsayısı sonuçlarının değerlendirilmesinde Hair vd. (2014) ve Kurtuluş (2015) tarafından belirtilen sınır değerleri esas alınmaktadır. KaiserMeyer-Olkin örneklem yeterliliği ölçümü için 0,60 sınır değeri, Bartlett's küresellik testi sonucu için $\mathrm{p}<0,050$, açıklanan toplam varyans değeri için en az $\% 50$, mümkün durumlarda $\% 60$ ve üzeri, Cronbach's Alpha güvenilirlik katsayısı için ise 0,60 ve üzeri sınırlar esas alınmaktadır. Araştırmadaki ölçüm araçlarının uygunluğunun değerlendirilmesinde söz konusu sınırlar gözetilerek yorumlama yapılmaktadır.

Tablo 2: Tüketicin Satın Alma Tarzı Ölçeğinin Faktör ve Güvenilirlik Analizi Sonuçları

\begin{tabular}{lcccc}
\hline Boyut & $\begin{array}{c}\text { Kaiser-Meyer-Olkin } \\
\text { örneklem yeterliliği }\end{array}$ & $\begin{array}{c}\text { Açıklanan } \\
\text { toplam varyans }\end{array}$ & $\begin{array}{c}\text { Güvenilirlik katsayısı } \\
\text { (Cronbach's Alpha) }\end{array}$ & $\begin{array}{c}\text { Madde } \\
\text { sayısı }\end{array}$ \\
\hline Tüketici satın alma tarzı & $\mathbf{0 , 8 2 9}$ & $\mathbf{6 1 , 5 6 3}$ & $\mathbf{0 , 8 0 7}$ & $\mathbf{2 8}$ \\
\hline Mükemmeliyetçilik & 0,848 & 54,482 & 0,818 & 6 \\
\hline Marka odaklılı & 0,762 & 51,658 & 0,760 & 5 \\
\hline Eğlence odaklılık & 0,739 & 69,994 & 0,856 & 4 \\
\hline Karmaşa yaşayanlar & 0,778 & 57,202 & 0,809 & 5 \\
\hline Dürtüsel alışveriş & 0,793 & 70,791 & 0,858 & 4 \\
\hline Fiyat odaklılık & 0,708 & 57,157 & 0,749 & 4 \\
\hline
\end{tabular}

Tablo 2'de tüketicilerin satın alma tarzı ölçeğinin ve ölçekte yer alan boyutların faktör analizi ve güvenilirlik analizi sonuçları birlikte yer almaktadır. Tabloda yer alan bütün ölçümler için Bartlett's küresellik testi sonucu $\mathrm{p}<0,050$ düzeyinde anlamlıdır. Tüketici satın alma tarzı ölçeğinin KMO değeri 0,829 , açıklanan toplam varyans değeri \%61,56 olarak tespit edilmiştir. Ölçeğin güvenilirlik katsayıs1 0,807 olarak gerçekleşirken, analizler sonucunda ölçekte 28 maddenin yer aldığ1 görülmektedir. Mükemmeliyetçilik boyutunun KMO değeri 0,848, açılanan toplam varyans değeri \%54,48 olarak tespit edilmiştir. Boyutun güvenilirlik katsayısı 0,818 olarak gerçekleşirken, analizler sonucunda boyutta 6 maddenin yer aldığ 1 görülmektedir. Mükemmeliyetçilik boyutunda yer alan "hoşuma giden bir ürün ya da marka bulduğum zaman, artık onu kolay kolay bırakmam" maddesi boyutun iki faktöre ayrılmasına neden olduğu için araştırma kapsamından çıkarılmıştır. Maddenin araştırma kapsamından çıkarılmasında Hair vd. (2014) tarafından uygun görülen kıstaslar (ölçekteki maddelerin varyanskovaryans matrisi oluşturacak sayıda olması, soru havuzundan atılması durumunda ölçüm aracının açıklama gücünün etkilenmesi, faktöre yüklenme düzeyi) göz önüne alınmıştır. Marka odaklılık boyutunun KMO değeri 0,762 , açıklanan toplam varyans değeri \%51,65 olarak tespit edilmiştir. Boyutun güvenilirlik katsayısı 0,760 olarak gerçekleşirken, analizler sonucunda boyutta 5 maddenin yer aldığı görülmektedir. Eğlence odaklılık boyutunun KMO değeri 0,739, açıklanan toplam varyans değeri \%69,99 olarak tespit edilmiştir. Eğlence odaklılık boyutunun güvenilirlik katsayısı 0,856 olarak gerçekleşirken, analizler sonucunda boyutta 4 maddenin yer aldığ görülmektedir. Karmaşa yaşama boyutunun KMO değeri 0,778, açıklanan toplam varyans değeri \%57,20 olarak tespit edilmiştir. Karmaşa yaşama boyutunun güvenilirlik katsayısı 0,809 olarak gerçekleşirken, analizler sonucunda boyutta 5 maddenin yer aldığı görülmektedir. Dürtüsel alışveriş boyutunun KMO değeri 0,793, açılanan toplam varyans değeri \%70,79 olarak tespit edilmiştir. Dürtüsel alışveriş boyutunun güvenilirlik katsayısı 0,858 olarak gerçekleşirken, analizler sonucunda boyutta 4 maddenin yer aldığ görülmektedir. Fiyat odaklılık boyutunun KMO değeri 0,708, açılanan toplam varyans değeri $\% 57,15$ olarak tespit edilmiştir. Fiyat odaklılık boyutunun güvenilirlik katsayısı 0,749 olarak gerçekleşirken, analizler sonucunda boyutta 4 maddenin yer aldığı görülmektedir. Tabloda yer alan bulgular genel olarak yorumlandığında, tüketici satın alma tarzı ölçeğinin, tüketicilerin satın alma tarzlarının ölçülmesi için uygun bir ölçüm aracı olduğunu ifade etmek mümkündür. 
Tablo 3: Sosyal Medya Reklamları Ölçeğinin Faktör ve Güvenilirlik Analizi Sonuçları

\begin{tabular}{lcccc}
\hline Boyut & $\begin{array}{c}\text { Kaiser-Meyer-Olkin } \\
\text { örneklem yeterliliği }\end{array}$ & $\begin{array}{c}\text { Açıklanan toplam } \\
\text { varyans }\end{array}$ & $\begin{array}{c}\text { Güvenilirlik sonucu } \\
\text { (Cronbach's Alpha) }\end{array}$ & Madde sayısı \\
\hline Sosyal medya reklamları & $\mathbf{0 , 9 2 0}$ & $\mathbf{6 8 , 4 9 3}$ & $\mathbf{0 , 9 3 3}$ & $\mathbf{1 2}$ \\
\hline Bilgi sağlama & 0,731 & 80,899 & 0,881 & 3 \\
\hline Eğlence sunma & 0,751 & 88,961 & 0,938 & 3 \\
\hline Güvenilir olma & 0,760 & 86,492 & 0,922 & 3 \\
\hline Ekonomiye katk1 & 0,692 & 67,319 & 0,757 & 3 \\
\hline
\end{tabular}

Tablo 3'te sosyal medya reklamları ölçeğinin ve ölçekte yer alan boyutların faktör analizi ve güvenilirlik analizi sonuçları birlikte yer almaktadır. Tabloda yer alan ölçüm sonuçlarının her birisi için Bartlett's küresellik testi sonucu $\mathrm{p}<0,050$ düzeyinde anlamlıdır. Sosyal medya reklamları ölçeğinin KMO değeri 0,920, açıklanan toplam varyans değeri \%68,49 olarak tespit edilmiştir. Ölçeğin güvenilirlik katsayısı 0,933 olarak gerçekleşirken, analizler sonucunda ölçekte 12 maddenin yer aldığ görülmektedir. Bilgi sağlama boyutunun KMO değeri 0,731, açılanan toplam varyans değeri \%80,89 olarak tespit edilmiştir. Bilgi sağlama boyutunun güvenilirlik katsayısı 0,881 olarak gerçekleşirken, analizler sonucunda boyutta 3 maddenin yer aldığı görülmektedir. Eğlence sunma boyutunun KMO değeri 0,751, açıklanan toplam varyans değeri \%88,96 olarak tespit edilmiştir. Eğlence sunma boyutunun güvenilirlik katsayısı 0,938 olarak gerçekleşirken, analizler sonucunda boyutta 3 maddenin yer aldığı görülmektedir. Güvenilir olma boyutunun KMO değeri 0,760 , açıklanan toplam varyans değeri $\% 86,49$ olarak tespit edilmiştir. Güvenilir olma boyutunun güvenilirlik katsayısı 0,922 olarak gerçekleşirken, analizler sonucunda boyutta 3 maddenin yer aldı̆̆ görülmektedir. Ekonomiye katk1 boyutunun KMO değeri 0,692, açıklanan toplam varyans değeri $\% 67,31$ olarak tespit edilmiştir. Ekonomiye katkı boyutunun güvenilirlik katsayısı 0,757 olarak gerçekleşirken, analizler sonucunda boyutta 3 maddenin yer aldığ görülmektedir. Analiz kapsamında sosyal medya reklamları ölçeğinden herhangi bir madde atılmamıştır. Ayrıca elde edilen bulgular doğrultusunda sosyal medya reklamları ölçeğinin tüketicilerin sosyal medya reklamları ile ilgili görüşlerini ölçmek için uygun bir araç olduğunu ifade etmek mümkündür.

Tablo 4: Mobil Satın Alma Niyeti Ölçeğinin Faktör ve Güvenilirlik Analizi Sonuçları

\begin{tabular}{lcccr}
\hline Boyut & $\begin{array}{c}\text { Kaiser-Meyer-Olkin Measure } \\
\text { of Sampling Adequacy }\end{array}$ & $\begin{array}{c}\text { Açıklanan toplam } \\
\text { varyans }\end{array}$ & $\begin{array}{c}\text { Güvenilirlik sonucu } \\
\text { (Cronbach's Alpha) }\end{array}$ & Madde sayısı \\
\hline Mobil satı alma niyeti & 0,772 & 67,887 & 0,840 & 4 \\
\hline
\end{tabular}

Tablo 4'te mobil satın alma niyeti ölçeğinin faktör analizi ve güvenilirlik analizi sonuçları birlikte yer almaktadır. Tabloda yer alan ölçüm sonuçları için Bartlett's küresellik testi sonucu $\mathrm{p}<0,050$ düzeyinde anlamlıdır. Sosyal medya reklamları ölçeğinin KMO değeri 0,772 , açıklanan toplam varyans değeri \%67,88 olarak tespit edilmiştir. Mobil satın alma niyeti ölçeğinin güvenilirlik katsayısı 0,840 olarak gerçekleşirken, analizler sonucunda ölçekte 4 maddenin yer aldığ1 görülmektedir. Faktör analizi sonucunda ölçekteki herhangi bir madde atılmamıştır. Elde edilen bulgular doğrultusunda mobil satın alma niyeti ölçeğinin tüketicilerin mobil cihazlardan alışveriş yapma niyetlerini yeterli şekilde ölçmek için uygun bir araç olduğunu ifade etmek mümkündür.

\subsection{Demografik Özellikler ve Tanımlayıcı İstatistikler}

Araştırmanın bu kısmında araştırma kapsamında yer alan tüketicilerin demografik özellikleri ve tüketicilerin satın alma eğilimleri, sosyal medya reklamları hakkındaki görüşleri ve mobil cihazları üzerinden satın alma niyetleri hakkında istatistiki bulgular yer almaktadır. 
Tablo 5: Katılımcıların Demografik Özellikleri

\begin{tabular}{|c|c|c|c|c|c|c|c|}
\hline Değișken & Özellik & Kişi & $\%$ & Değişken & Özellik & Kişi & $\%$ \\
\hline \multirow{3}{*}{ Cinsiyet } & Kadın & 693 & 59,6 & \multirow{4}{*}{$\begin{array}{l}\text { Sosyal medya } \\
\text { reklamlarına ilgi }\end{array}$} & İlgilenirim & 165 & 14,2 \\
\hline & Erkek & 469 & 40,4 & & Bazen ilgilenirim & 831 & 71,5 \\
\hline & Toplam & 1162 & 100,0 & & İlgilenmem & 166 & 14,3 \\
\hline \multirow{5}{*}{ Yaş } & 25 ve altında & 208 & 17,9 & & Toplam & 1162 & 100,0 \\
\hline & $26-35$ & 421 & 36,2 & \multirow{3}{*}{$\begin{array}{l}\text { Sosyal medyada } \\
\text { görerek satın alma }\end{array}$} & Evet & 818 & 70,4 \\
\hline & $36-45$ & 294 & 25,3 & & Hayır & 344 & 29,6 \\
\hline & 46 ve üzeri & 239 & 20,6 & & Toplam & 1162 & 100,0 \\
\hline & Toplam & 1162 & 100,0 & \multirow{5}{*}{$\begin{array}{l}\text { Mobil cihazdan } \\
\text { yapılan son } \\
\text { alışverişin zamanı }\end{array}$} & Yapmadım & 83 & 7,1 \\
\hline \multirow{3}{*}{$\begin{array}{l}\text { Medeni } \\
\text { durum }\end{array}$} & Evli & 596 & 51,3 & & Son 1 ayda & 809 & 69,6 \\
\hline & Bekâr & 566 & 48,7 & & Son 3 ayda & 141 & 12,1 \\
\hline & Toplam & 1162 & 100,0 & & 6 Ay ve üzeri & 129 & 11,2 \\
\hline \multirow{4}{*}{$\begin{array}{l}\text { Çocuk } \\
\text { sayısı }\end{array}$} & Çocuk yok & 656 & 56,5 & & Toplam & 1162 & 100,0 \\
\hline & 1 & 227 & 19,5 & \multirow{8}{*}{$\begin{array}{l}\text { Mobil cihazdan } \\
\text { yapılan } \\
\text { alışverişlerin } \\
\text { kategorisi }\end{array}$} & Yeme/içme & 157 & 13,5 \\
\hline & 2 ve üzeri & 280 & 24,0 & & Kozmetik & 105 & 9,0 \\
\hline & Toplam & 1162 & 100,0 & & Giyim & 316 & 27,2 \\
\hline \multirow{8}{*}{$\begin{array}{l}\text { Eğitim } \\
\text { durumu }\end{array}$} & $\mathrm{Jice}$ & & & & Market & 83 & 7,1 \\
\hline & Lise & 159 & 13,7 & & Kitap-Dergi & 154 & 13,3 \\
\hline & Önlisans & 85 & 7,3 & & Elektronik & 67 & 5,8 \\
\hline & & & & & Diğer & 280 & 24,1 \\
\hline & Lisans & 453 & 39,0 & & Toplam & 1162 & 100,0 \\
\hline & YL/doktora & 442 & 38,0 & \multirow{7}{*}{$\begin{array}{l}\text { Sosyal medya } \\
\text { reklamlarında en } \\
\text { çok karşılaşılan } \\
\text { ürün kategorisi }\end{array}$} & Giyim & 520 & 44,8 \\
\hline & Diğer & 23 & 2,0 & & Ayakkabı Çanta & 71 & 6,1 \\
\hline & Toplam & 1162 & 100,0 & & Kozmetik & 121 & 10,4 \\
\hline \multirow{5}{*}{$\begin{array}{l}\text { Gelir } \\
\text { düzeyi }\end{array}$} & 2500 ve altında & 276 & 23,8 & & $\mathrm{Ev}$ & 69 & 5,9 \\
\hline & $2501-5000$ arasında & 402 & 34,6 & & Elektronik & 81 & 7,0 \\
\hline & $5001-7500$ arasinda & 180 & 15,5 & & Diğer & 300 & 25,8 \\
\hline & 7501 ve üzeri & 294 & 25,3 & & Toplam & 1162 & 100,0 \\
\hline & Toplam & 1152 & 99,1 & \multirow{5}{*}{$\begin{array}{l}\text { Günlük internet } \\
\text { kullanımı }\end{array}$} & 1 saatten az & 32 & 2,8 \\
\hline Kayıp & Veri & 10 & ,9 & & $1-3$ saat & 448 & 38,6 \\
\hline Toplam & & 1162 & 100,0 & & 4-6 saat & 470 & 40,4 \\
\hline \multirow{5}{*}{ Meslek } & Öğrenci & 168 & 14,5 & & 7 saat ve daha fazla & 212 & 18,2 \\
\hline & Kamu & 352 & 30,3 & & Toplam & 1162 & 100,0 \\
\hline & Özel sektör & 373 & 32,1 & \multirow{3}{*}{\multicolumn{2}{|c|}{$\mathrm{N}: 1162$}} & & \\
\hline & Diğer & 269 & 23,1 & & & & \\
\hline & Toplam & 1162 & 100,0 & & & & \\
\hline
\end{tabular}

Katılımcıların demografik özellikleri ile ilgili özellikleri Tablo 5'te yer almaktadır. Katılımcıların \%59,6'sı kadınlardan oluşurken, \%40,4'ü ise erkeklerden oluşmaktadır. Katılımcıların $\% 17,9$ 'u 25 yaş altındaki, \%36,2'si 26-35 yaş aralığında, \%25,3'ü 36-45 yaş aralığında, \%20,6'sı ise 46 ve üzerindeki yaş grubunda yer alan tüketicilerden oluşmaktadır. Katılımcıların \%51,3'ü evli, \%48,7'si ise bekâr tüketicilerdir. Katılımciların \%56,6's1 çocuk sahibi değilken, \%19,5'i 1 çocuk, $\% 24$ 'ü ise 2 ve daha fazla sayıda çocuğa sahiptir. Katılımcıların \%13,7'si lise düzeyinde, \%7,3'ü ön lisans düzeyinde, $\% 39$ 'u lisans düzeyinde, $\% 38$ 'i lisansüstü düzeyinde eğitime sahipken $\% 2$ 'si ise diğer düzeylerde eğitime sahiptirler. Katılımcıların \%23,8'i 2500 TL ve altında, \%34,6's1 2501 ve $5000 \mathrm{TL}$ arasinda, \%15,5'i 5001 ve $7500 \mathrm{TL}$ arasinda, \%25,3'ü ise $7501 \mathrm{TL}$ ve üzerinde gelir seviyesine sahiptir. Katılımcıların $\% 0,9^{\prime} \mathrm{u}$ ise gelir düzeyi hakkında görüş bildirmemiştir. Katılımcıların \%14,5'i öğrenciler, \%30,3'ü kamu çalışanları, \%32,1'i özel sektör çalışanları, \%23,1'i diğer meslek grubunda yer alan tüketicilerden oluşmaktadır. Katılımcıların sosyal medya reklamlarıyla ilgilenme durumları incelendiğinde; katılımcıların \%14,2'sinin sosyal medya reklamları ile ilgilendiği, \%71,5'inin bazen ilgilendiği, \%14,3'ünün sosyal medya reklamları ile ilgilenmediği görülmektedir. Katılımcıların \%70,4'ü sosyal medyadan gördüğü bir ürünü satın alma işlemi gerçekleştirdiğini, \%29,6's1 ise satın alma işlemi gerçekleştirmediğini ifade etmektedir. Katılımcıların \%7,1'i mobil cihazlarından alışveriş yapmadığını belirtirken, \%69,6'sı son bir ay içerisinde, \%12,1'i son 3 ay içerisinde, \%11,2'si ise son 6 ay ve üzerindeki bir zaman diliminde mobil cihazlarını kullanarak alışveriş yaptığını ifade etmiştir. Katılımcıların mobil cihazlarından yaptıkları alışverişin \%13,5'i yeme-içme, \%9'u kozmetik, \%27,2'si giyim, \%7,1'i market, \%13,3'ü kitap-dergi, \%5,8'i elektronik, $\% 24,1$ 'i ise diğer kategorisinde gerçekleşmiştir. Katılımcıların sosyal medya reklamlarında en sık karşılaştıkları ürün kategorileri incelendiğinde; katılımcıların \%44,8'i giyim, \%6,1'i ayakkabı-çanta, 
\%10,4'ü kozmetik, \%5,9'u ev, \%7'si elektronik, \%25,8'i ise diğer ürün kategorilerinin olduğunu belirtmiştir. Son olarak, katılımcıların \%2,8'i günde 1 saatten az internet kullandığını belirtirken, \%38,6'sı 1-3 saat aralığında, \%40,4'ü 4-6 saat aralığında, \%18,2'si ise 7 saat ve üzerinde sürelerden günlük internet kullanımını sağladığını belirmiştir.

Tablo 6: Ölçüm Araçlarına Ait Tanımlayıcı İstatistikler

\begin{tabular}{lcc}
\hline Boyut & Ortalama & Std. Sapma \\
\hline Tüketici satın alma tarzı ölçeği & & \\
\hline Mükemmeliyetçilik & 4,1928 & 0,6509 \\
\hline Marka odaklılı & 2,6713 & 0,7761 \\
\hline Eğlence odaklılık & 2,9935 & 1,0808 \\
\hline Karmaşa yaşama & 2,9857 & 0,93265 \\
\hline Dürtüsel alışveriş & 2,2681 & 1,02908 \\
\hline Fiyat odaklılık & 3,8795 & 0,78764 \\
\hline Sosyal medya reklamları ölçeğinin & & \\
\hline Bilgi sağlama & 3,2547 & 1,05234 \\
\hline Güvenilir olma & 2,2883 & 0,98354 \\
\hline Ekonomiye katk1 & 2,8738 & 0,92959 \\
\hline Eğlence sunma & 2,5677 & 1,13592 \\
\hline Mobil satın alma & 2,7265 & 0,97919 \\
\hline
\end{tabular}

Araştırma kapsamında kullanılan ölçeklerde yer alan maddeler için katılımcıların belirtmiş oldukları görüşlere ait temel istatistiki sonuçlar Tablo 6'da yer almaktadır. Tüketici satın alma tarzı ölçeğinin alt boyutlarına verilen cevapların ortalaması incelendiğinde tüketicilerin; mükemmeliyetçilik odaklı oldukları, marka bilinçlerinin düşük olduğu, eğlence odaklılık açısından kararsız düzeyde oldukları görülmektedir. Ayrıca, tüketicilerin karmaşa yaşama konusunda çekimser düzeyde oldukları, düşünerek ve dikkatli şekilde alışveriş yapan kişiler oldukları ve yüksek düzeyde fiyat odaklı olduklarını ifade etmek mümkündür. Tüketicilerin sosyal medya reklamları ile ilgili görüşleri incelendiğinde; tüketicilerin sosyal medya reklamlarını kısmen bilgilendirici olarak gördüklerini ifade etmek mümkündür. Ancak tüketicilere göre sosyal medya reklamları düşük düzeyde güvenilir ve düşük düzeyde eğlencelidir. Sosyal medya reklamlarının ekonomiye katkısı hakkında ise tüketicilerin kararsız olduklarını ifade etmek mümkündür. Son olarak, tüketicilerin mobil cihazlarını kullanarak sosyal medyadan gördükleri ürünleri satın almada kararsız oldukları görülmektedir.

\subsection{Değişkenler Arasındaki İlişkiler}

Araştırmada yer alan değişkenlerin arasındaki ilişkilerin tespit edilebilmesi için yapılan korelasyon analizi değişkenler arasındaki ilişkilerin şiddeti ve yönü hakkında sonuçlar sağlamaktadır (Hair vd., 2014; Büyüköztürk vd., 2016). Korelasyon analizi sonucunda elde edilen ilişkiler p $<0,050$ olarak incelenmiștir. Araştırmada Pearson korelasyon analizi kullanılmıștır. Pearson korelasyon analizinin yapılmasında önemli bir ön şart olan normal dağılım şartının incelenmesi öncelikle Kolmogrov-Smirnov ve Shapiro-Wilk testleri yapılmıştır. Test sonuçlarının $\mathrm{p}<0,050$ düzeyinde olmasından dolayı normal dağılımın sağlanamadığı görülmüştür. Ankete dayalı çalışmalarda normal dağılım şartının sağlanmasının zor olduğunu bunun için çarpıklık ve basıklık değerlerinin incelenmesi uygun görülmektedir (George \& Mallery, 2010; Tabachnick \& Fidell, 2013). Analiz sonucunda çarpıklık değeri -851 ile +613 arasında, basıklık değeri ise -887 ile +651 arasında değerler almıştır. Çarpıklık ve basıklık değerleri için George ve Mallery (2010), Tabachnick ve Fidell (2013) ve Hair vd. (2014) tarafından uygun sınır değerleri $(+1,5$ ve $-1,5$ olarak) belirlenmiştir. Çarpıklık ve basıklık değerleri $+1,5$ ve $-1,5$ arasında olduğundan dolayı araştırmada kullanılan verilerin normal dağıldı̆̆ varsayılmaktadır. Normal dağ 11 ım varsayımı altında elde edilen Pearson korelasyon analizi sonucunda elde edilen bulgular ise Tablo 7'de sunulmaktadır. 
Tablo 7: Korelasyon Analizi Sonuçları

\begin{tabular}{|c|c|c|c|c|c|c|c|c|c|c|c|c|}
\hline & & 1 & 2 & 3 & 4 & 5 & 6 & 7 & 8 & 9 & 10 & 11 \\
\hline \multirow{2}{*}{$\begin{array}{l}\text { Mükemmelliy } \\
\text { etçilik (1) }\end{array}$} & $\begin{array}{l}\text { Pearson korelasyon } \\
\text { Anlamlıl1k (2-Kuyruk) }\end{array}$ & 1 & & & & & & & & & & \\
\hline & $\mathrm{N}$ & 1162 & & & & & & & & & & \\
\hline \multirow{3}{*}{$\begin{array}{l}\text { Marka } \\
\text { odaklılık (2) }\end{array}$} & Pearson korelasyon &, $332^{* *}$ & 1 & & & & & & & & & \\
\hline & Anlamlılık (2-Kuyruk) &, 000 & & & & & & & & & & \\
\hline & $\mathrm{N}$ & 1162 & 1162 & & & & & & & & & \\
\hline \multirow{3}{*}{$\begin{array}{l}\text { Eğlence } \\
\text { odaklılık (3) }\end{array}$} & Pearson korelasyon &, $257^{* *}$ &, $354^{* *}$ & 1 & & & & & & & & \\
\hline & Anlamlılık (2-Kuyruk) &, 000 & ,000 & & & & & & & & & \\
\hline & $\mathrm{N}$ & 1162 & 1162 & 1162 & & & & & & & & \\
\hline \multirow{3}{*}{$\begin{array}{l}\text { Karmaşa } \\
\text { yaşama (4) }\end{array}$} & Pearson korelasyon &, $081^{* *}$ & $309^{* *}$ &, $239^{* * *}$ & 1 & & & & & & & \\
\hline & Anlamlılık (2-Kuyruk) &, 006 &, 000 &, 000 & & & & & & & & \\
\hline & $\mathrm{N}$ & 1162 & 1162 & 1162 & 1162 & & & & & & & \\
\hline \multirow{3}{*}{$\begin{array}{l}\text { Dürtüsel } \\
\text { alışveriş (5) }\end{array}$} & Pearson korelasyon &,$- 129^{* *}$ &, $150^{* *}$ &,- 003 &, $186^{* *}$ & 1 & & & & & & \\
\hline & Anlamlılık (2-Kuyruk) &, 000 &, 000 & ,932 &, 000 & & & & & & & \\
\hline & $\mathrm{N}$ & 1162 & 1162 & 1162 & 1162 & 1162 & & & & & & \\
\hline \multirow{3}{*}{$\begin{array}{l}\text { Fiyat } \\
\text { odaklılık (6) }\end{array}$} & Pearson korelasyon & ,054 &,- 006 &,- 014 &, $095^{* *}$ &,$- 127^{* *}$ & 1 & & & & & \\
\hline & Anlamlılık (2-Kuyruk) &, 065 &, 845 & ,632 & ,001 & ,000 & & & & & & \\
\hline & $\mathrm{N}$ & 1162 & 1162 & 1162 & 1162 & 1162 & 1162 & & & & & \\
\hline \multirow{3}{*}{$\begin{array}{l}\text { Bilgi sağlama } \\
\text { (7) }\end{array}$} & Pearson korelasyon &, $106^{* *}$ &, $269^{* *}$ &, $294^{* *}$ &, $253^{* *}$ &, $072^{*}$ &, $198^{* *}$ & 1 & & & & \\
\hline & Anlamlılık (2-Kuyruk) &, 000 &, 000 & ,000 &, 000 & ,015 &, 000 & & & & & \\
\hline & $\mathrm{N}$ & 1162 & 1162 & 1162 & 1162 & 1162 & 1162 & 1162 & & & & \\
\hline \multirow{3}{*}{$\begin{array}{l}\text { Güvenilir } \\
\text { olma (8) }\end{array}$} & Pearson korelasyon &, $088^{* *}$ &, $369^{* *}$ &, $249^{* * *}$ &, $186^{* *}$ & $157^{* *}$ &, $076^{* *}$ &, $561^{* *}$ & 1 & & & \\
\hline & Anlamlılık (2-Kuyruk) &, 003 &, 000 & 000 &, 000 & 000 &, 010 &, 000 & & & & \\
\hline & $\mathrm{N}$ & 1162 & 1162 & 1162 & 1162 & 1162 & 1162 & 1162 & 1162 & & & \\
\hline \multirow{3}{*}{$\begin{array}{l}\text { Ekonomiye } \\
\text { katk1 (9) }\end{array}$} & Pearson korelasyon & $104^{* *}$ &, $294^{* *}$ &, $251^{* *}$ &, $195^{* *}$ & $106^{* *}$ & $122^{* * *}$ &, $572^{* * *}$ & $675^{* *}$ & 1 & & \\
\hline & Anlamlılık (2-Kuyruk) &, 000 &, 000 &, 000 &, 000 & 000 &, 000 &, 000 &, 000 & & & \\
\hline & $\mathrm{N}$ & 1162 & 1162 & 1162 & 1162 & 1162 & 1162 & 1162 & 1162 & 1162 & & \\
\hline \multirow{3}{*}{$\begin{array}{l}\text { Eğlence } \\
\text { sunma (10) }\end{array}$} & Pearson korelasyon &, $110^{* * *}$ &, $317^{* * *}$ &, $303^{* * *}$ &, $225^{* * *}$ &, $112^{* * *}$ & ,049 &, $587^{* * *}$ &, $731^{* *}$ &, $589^{* * *}$ & 1 & \\
\hline & Anlamlılık (2-Kuyruk) &, 000 &, 000 &, 000 &, 000 &, 000 & ,094 &, 000 &, 000 &, 000 & & \\
\hline & 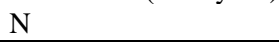 & 1162 & 1162 & 1162 & 1162 & 1162 & 1162 & 1162 & 1162 & 1162 & 1162 & \\
\hline \multirow{3}{*}{$\begin{array}{l}\text { Mobil satın } \\
\text { alma (11) }\end{array}$} & Pearson korelasyon & $125^{* * *}$ &, $315^{* *}$ &, $346^{* *}$ &, $248^{* * *}$ &, $084^{* * *}$ &, $094^{* * *}$ &, $549^{* *}$ & $626^{* *}$ &, $629^{* *}$ &, $539^{* *}$ & 1 \\
\hline & Anlamlılık (2-Kuyruk) &, 000 &, 000 &, 000 &, 000 & ,004 &, 001 &, 000 & ,000 & ,000 & ,000 & \\
\hline & $\mathrm{N}$ & 1162 & 1162 & 1162 & 1162 & 1162 & 1162 & 1162 & 1162 & 1162 & 1162 & 1162 \\
\hline
\end{tabular}

**. Korelasyon 0.01 seviyesinde anlamlı (2-kuyruk). *. Korelasyon 0.05 seviyesinde anlamlı (2-kuyruk).

Tüketici satın alma tarzı, sosyal medya reklamları ve mobil alışveriş niyeti arasındaki ilişkilerin tespit edilebilmesi için yapılan korelasyon analizi sonuçları incelendiğinde; tüketicilerin mükemmeliyetçilik odaklı satın alma eğilimleri ile sosyal medya reklamlarının alt boyutlarından bilgi sağlama, güvenilir olma, ekonomiye katkı ve eğlence sunma arasında düşük düzeyde, pozitif yönlü ve istatistiki olarak $(\mathrm{p}<0,010)$ anlamlı ilişkiler olduğu görülmektedir. Tüketicilerin marka odaklı satın alma eğilimleri ile sosyal medya reklamlarının bilgi sağlama, güvenilir olma, ekonomiye katkı sağlama ve eğlence sunma boyutları arasında düşük düzeyde, pozitif yönlü ve istatistiki olarak $(p<0,010)$ anlamlı ilişkilerin olduğu görülmektedir. Tüketicilerin eğlence ve haz odaklı satın alma eğilimleri ile sosyal medya reklamlarının bilgi sağlama, güvenilir olma, ekonomiye katkı sağlama ve eğlence sunma boyutları arasında düşük düzeyde, pozitif yönlü ve istatistiki olarak $(p<0,010)$ anlamlı ilişkilerin olduğu görülmektedir. Tüketicilerin karmaşıklık altında satın alma eğilimi ile sosyal medya reklamlarının bilgi sağlama, güvenilir olma, ekonomiye katkı sağlama ve eğlence sunma boyutları arasında düşük düzeyde, pozitif yönlü ve istatistiki olarak $(p<0,010)$ anlamlı ilişkilerin olduğu görülmektedir. Tüketicilerin dürtüsel şekilde alışveriş yapma eğilimleri ile sosyal medya reklamlarının bilgi sağlama özelliği arasında düşük düzeyde, pozitif yönde ve istatistiki olarak $(p<0,050)$ anlamlı ilişki olduğu tespit edilmiştir. Bunun yanında tüketicilerin dürtüsel şekilde alışveriş yapma eğilimleri ile sosyal medya reklamlarının güvenilir olma, ekonomiye katkı sağlama ve eğlence sunma boyutları arasında da düşük düzeyde, pozitif yönlü ve istatistiki olarak $(\mathrm{p}<0,010)$ anlamlı ilişkilerin olduğu görülmektedir. Tüketicilerin fiyat odaklı satın alma eğilimleri ile sosyal medya reklamlarının bilgi sağlama, güvenilir olma, ekonomiye katkı sağlama boyutları arasında düşük düzeyde, pozitif yönlü ve istatistiki olarak $(p<0,010)$ anlamlı ilişkilerin olduğu görülmektedir. Fiyat odaklı alışveriş ile sosyal medya reklamlarının eğlence sunma özelliği arasından ise istatistiki olarak $(\mathrm{p}<0,050)$ anlamlı bir ilişki olmadığı tespit edilmiştir. 
Mobil cihazlarından satın alma niyetleri ile satın alma tarzlarının alt boyutlarından mükemmeliyetçilik, marka odaklılık, eğlence odakl11ık, karmaşa yaşama, dürtüsel alışveriş ve fiyat odaklılık arasında düşük düzeyde, pozitif yönlü ve istatistiki olarak $(\mathrm{p}<0,010)$ anlamlı ilişkilerin olduğu görülmektedir. Elde edilen sonuçlara göre tüketici satın alma tarzları ile mobil satın alma niyeti arasında incelenmekte olan tüm ilişkiler istatistiki olarak anlamlıdır. Tüketicilerin mobil cihazlarından satın alma eğilimler ile sosyal medya reklamları arasında ilişkiler incelendiğinde mobil satın alma niyeti ile sosyal medya reklamlarının alt boyutu olan bilgi sağlama, güvenilir olma, ekonomiye katkı sağlama ve eğlence sunma arasında orta düzeyde, pozitif yönde ve istatistiki olarak $(p<0,010)$ anlamlı ilişkilerin olduğu görülmektedir. Sosyal medya reklamlarının tüm alt boyutları ile mobil satın alma niyeti arasındaki ilişkiler istatistiki olarak anlamlıdır.

Korelasyon analizi sonucunda tüketicilerin satın alma tarzları, sosyal medya reklamlarını algılama biçimleri ve mobil satın alma niyetleri arasında anlamlı ilişkiler olduğu tespit edilmiştir. Elde edilen ilişkiler, değişkenlerin arasındaki nedensellik ilişkilerinin belirlenebilmesi açısından önem taşımaktadır. Değişkenler arasındaki ilişkilerin anlamlılı̆̆ından dolayı tüm değişkenler nedensellik ilişkilerinin tespit edilmesinde kullanılacak olan SPSS Process 2.16 makrosundaki modellere dâhil edilebilecektir.

\subsection{Aracılık (Mediyatör) Etkisinin Test Edilmesi}

Bağımlı değişken ve bağımsız değişkenlerin arasındaki nedensellik ilişkilerinde aracı değişkenlerin rolünün incelenmesi için SPSS Process 2.16 makrosunda yer alan 4 numaralı model kullanılmıştır. Söz konusu model, araştırmanın ana modelinin değişkenler bazında incelenmesine imkân vermektedir. Bağımsız değişkenin bağımlı değişkene etkisinde aracı değişkenin (mediyatör) rolünün incelenmesinde ilk olarak bağımsız değişkenin bağımlı değişkene etkisi sonucunda elde edilen katsayı ve anlamlılık düzeyi incelenmektedir. İkinci olarak, modele aracı değişken dâhil edilmektedir. Aracı değişkenin modele dâhil edilmesinden sonra bağımsız değişkenin bağımlı değiş̧keni açıklama düzeyinde ve anlamlılık seviyesinde $(\mathrm{p}<0,050)$ meydana gelen değişmeler kontrol edilmektedir. Aracı değişken modele girdikten sonra, bağımsız değişkenin bağımlı değişkeni açıklama düzeyi veya açıklama düzeyinin anlamlılığı değişirse aracılık etkisinden söz edilebilmektedir. Aracı değiş̧ken modele dâhil olduktan sonra, anlamlılığın tamamen bozulması tam aracılık etkisini, anlamlılığın değişmesi, ancak p $>0,050$ olmaması ve katsayıda önemli derecede azalma olması durumunda ise kısmi aracılık etkisini ifade etmektedir. Ayrıca elde edilen sonuçların güvenilirliği için alt seviye güven $\operatorname{aralığı~(LLCI)~ve~üst~seviye~güven~aralığı~(ULCI)~değerleri~esas~alınmaktadır.~Söz~konu~değerler~}$ arasında 0 (sıfır) noktasının olmaması elde edilen sonuçların güvenilirliğini göstermektedir (Hayes, 2018). Bağımsız değişkenin bağımlı değişkeni açıklamasındaki düşüşün aracilık değişkeninden kaynaklanması durumu Sobel testi ile incelenmektedir (Sobel, 1982,1986; Y1lmaz \& Dalbudak, 2018). Aracılık analizi sonuçları aşağıda yer almaktadır. Tabloları oluşturulurken sadece istatistiki olarak anlamlı bulgulara yer verilmiştir. Anlamlı olmayan bulgulara açılamalarda yer verilmiştir.

Tablo 8: Tüketici Satın Alma Tarzının Mobil Satın Alma Niyetine Etkisinde Eğlence Sunma Boyunun Aracilik Rolü

\begin{tabular}{lllllllllll}
\hline \multicolumn{2}{c}{ Değişkenler arası ilişkiler } & Model özeti & & Toplam etki & $\begin{array}{c}\text { Endirekt etki } \\
\text { güvenilirliği }\end{array}$ & $\begin{array}{c}\text { Sobel } \\
\text { test }\end{array}$ \\
\hline Bağımsız (X) & $\begin{array}{l}\text { Aracı } \\
(\mathbf{M})\end{array}$ & Bağımıı (Y) & $\mathbf{R}^{\mathbf{2}}$ & Katsayı & $\mathbf{P}$ & $\mathbf{R}^{\mathbf{2}}$ & Katsayı & LLCI & ULCI & $\mathbf{P}$ \\
\hline Mükemmeliyetçilik & $\begin{array}{l}\text { Eğlence } \\
\text { sunma }\end{array}$ & $\begin{array}{l}\text { Mobil satın } \\
\text { alma niyeti }\end{array}$ &, 2944 &, 0998 &, 000 &, 0156 &, 1879 &, 0405 &, 1413 &, 0002 \\
\hline Marka odaklı1ık & $\begin{array}{l}\text { Eğlence } \\
\text { sunma }\end{array}$ & $\begin{array}{l}\text { Mobil satın } \\
\text { alma niyeti }\end{array}$ &, 3131 &, 2019 &, 000 &, 0991 &, 3972 &, 1542 &, 2391 &, 0000 \\
\hline Eğlence odaklılık & $\begin{array}{l}\text { Eğlence } \\
\text { sunma }\end{array}$ & $\begin{array}{l}\text { Mobil satın } \\
\text { alma niyeti }\end{array}$ &, 3268 &, 1822 &, 000 &, 1195 &, 3132 &, 1018 &, 1628 &, 0000 \\
\hline Karmaşa yaşama & $\begin{array}{l}\text { Eğlence } \\
\text { sunma }\end{array}$ & $\begin{array}{l}\text { Mobil satın } \\
\text { alma niyeti }\end{array}$ &, 3070 &, 1402 &, 000 &, 0615 &, 2603 &, 0848 &, 1562 &, 0000 \\
\hline
\end{tabular}

Tüketicilerin satın alma tarzlarının mobil satın alma niyetine etkisinde sosyal medya reklamlarının eğlenceli olmasının aracılık rolünün incelenmesi için yapılan analiz sonuçları Tablo 8'de yer almaktadır. Tabloda yer alan bulgular incelendiğinde, mükemmeliyetçilik odaklı satın alma eğiliminin mobil cihazlardan alışveriş yapma niyetine etkisi \%1,56 (Bağımsız değişken katsayısı: 
0,1879) olarak gerçekleşmiştir. Mükemmeliyetçilik odaklı satın alma eğiliminin mobil cihazlardan alışveriş yapma niyetine etkisinde sosyal medya reklamlarının eğlence sunma özelliğinin aracılık rolünün incelendiği modelin toplam açıklama düzeyi ise \%29,44 (Bağımsız değişken katsayısı: 0,0998) olarak gerçekleşmiştir. Ancak aracı değişkenin modele dâhil olması ile birlikte mükemmeliyetçilik odaklı satın alma eğiliminin mobil satın alma niyetini açıklama düzeyini ifade eden katsayının düştüğü görülmektedir. Katsayı değerindeki düşüşe bağlı olarak; mükemmeliyetçilik odaklı satın alma eğilimindeki tüketicilerin mobil cihazlardan satın alma işlemi gerçekleştirme niyetlerinde, sosyal medya reklamlarının eğlence sunma özelliğinin kısmi aracılık etkisinin olduğunu ifade etmek mümkündür.

Marka odaklı satın alma eğiliminin mobil cihazlardan alışveriş yapma niyetine etkisi \%9,91 (Bağımsız değişken katsayısı: 0,3972) olarak gerçekleşmiş̧ir. Marka odaklı satın alma eğiliminin mobil cihazlardan alışveriş yapma niyetine etkisinde sosyal medya reklamlarının eğlence sunma özelliğinin aracılık rolünün incelendiği modelin toplam açıklama düzeyi ise \%31,31 (Bağımsız değiş̧ken katsayısı: 0,2019) olarak gerçekleşmiştir. Ancak aracı değişkenin modele dâhil olması ile birlikte marka odaklı satın alma eğiliminin, mobil satın alma niyetini açıklama düzeyini ifade eden katsayının düştüğü görülmektedir. Katsayı değerindeki düşüşe bağlı olarak; marka odaklı satın alma eğilimindeki tüketicilerin mobil cihazlardan satın alma işlemi gerçekleştirme niyetlerinde, sosyal medya reklamlarının eğlence sunma özelliğinin kısmi aracılık etkisinin olduğunu ifade etmek mümkündür.

Eğlence ve haz odaklı satın alma eğiliminin mobil cihazlardan alışveriş yapma niyetine etkisi \%11,95 (Bağımsız değişken katsayısı: 0,3132) olarak gerçekleşmiştir. Eğlence ve haz odaklı satın alma eğiliminin mobil cihazlardan alışveriş yapma niyetine etkisinde sosyal medya reklamlarının eğlence sunma özelliğinin aracılık rolünün incelendiği modelin toplam açılama düzeyi ise $\% 32,68$ (Bağımsız değişken katsayısı: 0,1822) olarak gerçekleşmiştir. Ancak aracı değişkenin modele dâhil olması ile birlikte eğlence ve haz odaklı satın alma eğiliminin, mobil satın alma niyetini açıklama düzeyini ifade eden katsayının düştüğü görülmektedir. Katsayı değerindeki düşüşe bağlı olarak; eğlence ve haz odaklı satın alma eğilimindeki tüketicilerin mobil cihazlardan satın alma işlemi gerçekleştirmelerinde sosyal medya reklamlarının eğlence sunma özelliğinin kısmi aracılık etkisine sahip olduğunu ifade etmek mümkündür.

Karmaşa yaşayanların satın alma eğiliminin mobil cihazlardan alışveriş yapma niyetine etkisi \%6,15 (Bağımsız değişken katsayısı: 0,2603) olarak gerçekleşmiştir. Karmaşa yaşayanların satın alma eğiliminin mobil cihazlardan alışveriş yapma niyetine etkisinde sosyal medya reklamlarının eğlence sunma özelliğinin aracılık rolünün incelendiği modelin toplam açıklama düzeyi ise \%30,70 (Bağımsız değiş̧ken katsayısı: 0,1402) olarak gerçekleşmiştir. Ancak aracı değişkenin modele dâhil olması ile birlikte karmaşa yaşayanların satın alma eğiliminin, mobil satın alma niyetini açıklama düzeyini ifade eden katsayının düştüğü görülmektedir. Katsayı değerindeki düşüşe bağlı olarak; karmaşa yaşayanların satın alma eğilimindeki tüketicilerin mobil cihazlardan satın alma işlemi gerçekleştirmelerinde sosyal medya reklamlarının eğlence sunma özelliğinin kısmi aracılık etkisine sahip olduğunu ifade etmek mümkündür. Dürtüsel alışveriş ile fiyat odaklı alışverişin mobil cihazlardan satın almaya etkisinde sosyal medya reklamlarının eğlence sunma özelliğinin aracılık rolünün olmadığı tespit edilmiştir.

Tablo 9: Tüketici Satın Alma Tarzının Mobil Satın Alma Niyetine Etkisinde Ekonomiye Katkı Boyunun Aracılık Rolü

\begin{tabular}{|c|c|c|c|c|c|c|c|c|c|c|}
\hline \multicolumn{3}{|c|}{ Değişkenler arası ilişkiler } & \multicolumn{3}{|c|}{ Model özeti } & \multicolumn{2}{|c|}{ Toplam etki } & \multicolumn{2}{|c|}{$\begin{array}{c}\text { Endirekt etki } \\
\text { güvenilirliği }\end{array}$} & \multirow{2}{*}{$\begin{array}{c}\begin{array}{c}\text { Sobel } \\
\text { test }\end{array} \\
P \\
\end{array}$} \\
\hline Bağımsız (X) & $\operatorname{Araci}\left(M_{x}\right)$ & Bağımlı (Y) & $\mathbf{R}^{2}$ & Katsayı & $\mathbf{P}$ & $\mathbf{R}^{2}$ & Katsayı & LLCI & ULCI & \\
\hline $\begin{array}{l}\text { Marka ve } \\
\text { fiyat: kalite } \\
\text { bilinci }\end{array}$ & $\begin{array}{l}\text { Ekonomiye } \\
\text { katk1 }\end{array}$ & $\begin{array}{l}\text { Mobil satın } \\
\text { alma niyeti }\end{array}$ & ,4138 &, 1798 &, 000 & ,0991 & ,3972 &, 1704 & ,2639 &, 0000 \\
\hline $\begin{array}{l}\text { Eğlence } \\
\text { odaklılık }\end{array}$ & $\begin{array}{l}\text { Ekonomiye } \\
\text { katk1 }\end{array}$ & $\begin{array}{l}\text { Mobil satın } \\
\text { alma niyeti }\end{array}$ & ,4329 & , 1815 &, 000 & , 1195 & ,3132 & ,0992 &, 1639 &, 0000 \\
\hline $\begin{array}{l}\text { Karmaşa } \\
\text { yaşama }\end{array}$ & $\begin{array}{l}\text { Ekonomiye } \\
\text { katk1 }\end{array}$ & $\begin{array}{l}\text { Mobil satın } \\
\text { alma niyeti }\end{array}$ & ,4116 & , 1369 &, 000 & ,0615 & ,2603 & ,0830 &, 1627 & ,0000 \\
\hline
\end{tabular}


Tüketicilerin satın alma tarzlarının mobil satın alma niyetine etkisinde sosyal medya reklamlarının ekonomik katkılarının aracılık rolünün incelenmesi için yapılan analiz sonuçları Tablo 9'da yer almaktadır. Marka odaklı satın alma eğiliminin mobil cihazlardan alışveriş yapma niyetine etkisi \%9,91 (Bağımsız değişken katsayısı: 0,3972) olarak gerçekleşmiştir. Marka odaklı satın alma eğiliminin mobil cihazlardan alışveriş yapma niyetine etkisinde sosyal medya reklamlarının ekonomiye katkı özelliğinin aracılık rolünün incelendiği modelin toplam açıklama düzeyi ise $\% 41,38$ (Bağımsız değişken katsayısı: 0,1798) olarak gerçekleşmiştir. Ancak aracı değişkenin modele dâhil olması ile birlikte marka odaklı satın alma eğiliminin, mobil satın alma niyetini açıklama düzeyini ifade eden katsayının düştüğü görülmektedir. Katsayı değerindeki düşüşe bağlı olarak; marka odaklı satın alma eğilimindeki tüketicilerin mobil cihazlardan satın alma işlemi gerçekleştirmelerinde sosyal medya reklamlarının ekonomik katkı sağlama özelliğinin kısmi aracılık etkisine sahip olduğunu ifade etmek mümkündür.

Eğlence ve haz odaklı satın alma eğiliminin mobil cihazlardan alışveriş yapma niyetine etkisi \%11,95 (Bağımsız değişken katsayısı: 0,3132) olarak gerçekleşmiştir. Eğlence ve haz odaklı eğilimle satın almanın mobil cihazlardan alı̧̧veriş yapma niyetine etkisinde sosyal medya reklamlarının ekonomiye katkı özelliğinin aracılık rolünün incelendiği modelin toplam açıklama düzeyi ise $\% 43,29$ (Bağımsız değişken katsayısı: 0,1815) olarak gerçekleşmiştir. Ancak aracı değişkenin modele dâhil olması ile birlikte eğlence ve haz odaklı satın alma eğiliminin, mobil satın alma niyetini açıklama düzeyini ifade eden katsayının düştüğü görülmektedir. Katsayı değerindeki düşüşe bağlı olarak; eğlence ve haz odaklı satın alma eğilimindeki tüketicilerin mobil cihazlardan satın alma işlemi gerçekleştirmelerinde sosyal medya reklamlarının ekonomik katkı sağlama özelliğinin kısmi aracılık etkisine sahip olduğunu ifade etmek mümkündür.

Karmaşa yaşayanların satın alma eğiliminin mobil cihazlardan alışveriş yapma niyetine etkisi \%6,15 (Bağımsız değişken katsayısı: 0,2603) olarak gerçekleşmiştir. Eğlence ve haz odaklı eğilimle satın almanın mobil cihazlardan alı̧̧veriş yapma niyetine etkisinde sosyal medya reklamlarının ekonomiye katkı özelliğinin aracılık rolünün incelendiği modelin toplam açıklama düzeyi ise $\% 41,16$ (Bağımsız değişken katsayısı: 0,1369) olarak gerçekleşmiştir. Ancak aracı değişkenin modele dâhil olması ile birlikte karmaşa yaşayanların satın alma eğiliminin, mobil satın alma niyetini açıklama düzeyini ifade eden katsayının düştüğü görülmektedir. Katsayı değerindeki düşüşe bağlı olarak; karmaşa yaşayanların satın alma eğilimindeki tüketicilerin mobil cihazlardan satın alma işlemi gerçekleştirmelerinde sosyal medya reklamlarının ekonomik katkı sağlama özelliğinin kısmi aracılık etkisine sahip olduğunu ifade etmek mümkündür. Mükemmeliyetçilik, dürtüsel alışveriş ile fiyat odaklı alışverişin mobil cihazlardan satın almaya etkisinde sosyal medya reklamlarının ekonomik katk1 özelliğinin aracılık rolünün olmadı̆̆ tespit edilmiştir.

Tablo 10: Tüketici Satın Alma Tarzının Mobil Satın Alma Niyetine Etkisinde Güvenilir Olma Boyunun Aracilık Rolü

\begin{tabular}{lllllllllll}
\hline \multicolumn{2}{c}{ Değişkenler arası ilişkiler } & & Model özeti & & \multicolumn{2}{c}{ Toplam etki } & \multicolumn{2}{c}{$\begin{array}{c}\text { Endirekt etki } \\
\text { güvenilirliği }\end{array}$} & $\begin{array}{c}\text { Sobel } \\
\text { test }\end{array}$ \\
\hline $\begin{array}{l}\text { Bağımsız } \\
(\mathbf{X})\end{array}$ & Aracı $\left(\mathbf{M}_{\mathbf{x}}\right)$ & Bağımlı (Y) & $\mathbf{R}^{2}$ & Katsayı & $\mathbf{P}$ & $\mathbf{R}^{2}$ & Katsayı & LLCI & ULCI & P \\
\hline $\begin{array}{l}\text { Marka } \\
\text { odaklılık }\end{array}$ & $\begin{array}{l}\text { Güvenilir } \\
\text { olma }\end{array}$ & $\begin{array}{l}\text { Mobil satın } \\
\text { alma niyeti }\end{array}$ &, 3999 &, 1229 &, 000 &, 0991 &, 3972 &, 2307 &, 3225 &, 0000 \\
\hline $\begin{array}{l}\text { Eğlence } \\
\text { odaklılık }\end{array}$ & $\begin{array}{l}\text { Güvenilir } \\
\text { olma }\end{array}$ & $\begin{array}{l}\text { Mobil satın } \\
\text { alma niyeti }\end{array}$ &, 4302 &, 1836 &, 000 &, 1195 &, 3132 &, 0973 &, 1637 &, 0000 \\
\hline $\begin{array}{l}\text { Karmaşa } \\
\text { yaşama }\end{array}$ & $\begin{array}{l}\text { Güvenilir } \\
\text { olma }\end{array}$ & $\begin{array}{l}\text { Mobil satın } \\
\text { alma niyeti }\end{array}$ &, 4096 &, 1430 &, 000 &, 0615 &, 2603 &, 0775 &, 1596 &, 0000 \\
\hline
\end{tabular}

Marka odaklı satın alma eğiliminin mobil cihazlardan alışveriş yapma niyetine etkisi \%09,91 (Bağımsız değişken katsayısı: 0,3972) olarak gerçekleşmiş̧ir. Marka odaklı satın alma eğiliminin mobil cihazlardan alışveriş yapma niyetine etkisinde sosyal medya reklamlarının güvenilir olma özelliğinin aracılık rolünün incelendiği modelin toplam açılama düzeyi ise \%39,99 (Bağımsız değişken katsayısı: 0,1229) olarak gerçekleşmiştir. Ancak aracı değiş̧kenin modele dâhil olması ile birlikte marka odaklı satın alma eğiliminin, mobil satın alma niyetini açılama düzeyini ifade eden katsayının düştüğü görülmektedir. Katsayı değerindeki düşüşe bağlı olarak; marka odaklı satın alma 
eğilimindeki tüketicilerin mobil cihazlardan satın alma işlemi gerçekleştirmelerinde sosyal medya reklamlarının güvenilirlik özelliğinin kısmi aracılık etkisine sahip olduğunu ifade etmek mümkündür.

Eğlence ve haz odaklı satın alma eğiliminin mobil cihazlardan alışveriş yapma niyetine etkisi \%11,95 (Bağımsız değişken katsayısı: 0,3132) olarak gerçekleşmiştir. Eğlence ve haz odaklı eğilimle satın almanın mobil cihazlardan alışveriş yapma niyetine etkisinde sosyal medya reklamlarının güvenilir olma özelliğinin aracılık rolünün incelendiği modelin toplam açıklama düzeyi ise \%43,02 (Bağımsız değişken katsayısı: 0,1836) olarak gerçekleşmiştir. Ancak aracı değişkenin modele dâhil olması ile birlikte eğlence ve haz odaklı satın alma eğiliminin, mobil satın alma niyetini açıklama düzeyini ifade eden katsayının düştüğü görülmektedir. Katsayı değerindeki düşüşe bağlı olarak; eğlence ve haz odaklı satın alma eğilimindeki tüketicilerin mobil cihazlardan satın alma işlemi gerçekleştirmelerinde sosyal medya reklamlarının güvenilir olma özelliğinin kısmi aracılık etkisine sahip olduğunu ifade etmek mümkündür.

Karmaşa yaşayanların satın alma eğiliminin mobil cihazlardan alışveriş yapma niyetine etkisi \%6,15 (Bağımsız değişken katsayısı: 0,2603) olarak gerçekleşmiştir. Eğlence ve haz odaklı eğilimle satın almanın mobil cihazlardan alışveriş yapma niyetine etkisinde sosyal medya reklamlarının güvenilir olma özelliğinin aracılık rolünün incelendiği modelin toplam açılama düzeyi ise $\% 40,96$ (Bağımsız değişken katsayısı: 0,1430) olarak gerçekleşmiştir. Ancak aracı değişkenin modele dâhil olması ile birlikte karmaşa yaşayanların satın alma eğiliminin, mobil satın alma niyetini açıklama düzeyini ifade eden katsayının düştüğü görülmektedir. Katsayı değerindeki düşüşe bağlı olarak; karmaşa yaşayanların satın alma eğilimindeki tüketicilerin mobil cihazlardan satın alma işlemi gerçekleştirmelerinde sosyal medya reklamlarının güvenilir olmasının kısmi aracılık etkisine sahip olduğunu ifade etmek mümkündür. Mükemmeliyetçilik, dürtüsel alışveriş ile fiyat odaklı alışverişin mobil cihazlardan satın almaya etkisinde sosyal medya reklamlarının güvenilir olmasının aracılık rolünün olmadığı tespit edilmiştir.

Tablo 11: Tüketici Satın Alma Tarzının Mobil Satın Alma Niyetine Etkisinde Bilgi Sağlama Boyunun Aracilık Rolü

\begin{tabular}{|c|c|c|c|c|c|c|c|c|c|c|}
\hline \multicolumn{3}{|c|}{ Değişkenler arası ilişkiler } & \multicolumn{3}{|c|}{ Model özeti } & \multicolumn{2}{|c|}{ Toplam etki } & \multicolumn{2}{|c|}{$\begin{array}{c}\text { Endirekt etki } \\
\text { güvenilirliği }\end{array}$} & \multirow{2}{*}{$\begin{array}{c}\begin{array}{c}\text { Sobel } \\
\text { test }\end{array} \\
P\end{array}$} \\
\hline Bağımsız (X) & $\begin{array}{l}\text { Aracı } \\
\left(\mathbf{M}_{\mathbf{x}}\right)\end{array}$ & $\begin{array}{l}\text { Bağımlı } \\
\text { (Y) }\end{array}$ & $\mathbf{R}^{2}$ & Katsayı & $\mathbf{P}$ & $\mathbf{R}^{2}$ & Katsayı & LLCI & ULCI & \\
\hline Mükemmeliyetçilik & $\begin{array}{l}\text { Bilgi } \\
\text { sağlama }\end{array}$ & $\begin{array}{l}\text { Mobil } \\
\text { satın alma } \\
\text { niyeti }\end{array}$ & ,3062 & ,1011 & ,006 &, 0156 & , 1879 &, 0380 &, 1383 &, 0003 \\
\hline Marka odaklılık & $\begin{array}{l}\text { Bilgi } \\
\text { sağlama }\end{array}$ & $\begin{array}{l}\text { Mobil } \\
\text { satın alma } \\
\text { niyeti }\end{array}$ &, 3318 & ,2271 &, 000 & ,0991 & ,3972 &, 1311 &, 2127 &, 0000 \\
\hline Eğlence odakl1lık & $\begin{array}{l}\text { Bilgi } \\
\text { sağlama }\end{array}$ & $\begin{array}{l}\text { Mobil } \\
\text { satın alma } \\
\text { niyeti }\end{array}$ &, 3388 & , 1825 &, 000 &, 1195 & ,3132 &, 1017 &, 1619 &, 0000 \\
\hline Karmaşa yaşama & $\begin{array}{l}\text { Bilgi } \\
\text { sağlama }\end{array}$ & $\begin{array}{l}\text { Mobil } \\
\text { satın alma } \\
\text { niyeti }\end{array}$ &, 3144 & ,1221 &, 000 &, 0615 & ,2603 &, 1026 &, 1738 &, 0000 \\
\hline
\end{tabular}

Mükemmeliyetçilik odaklı satın alma eğiliminin mobil cihazlardan alışveriş yapma niyetine etkisi \%1,56 (Bağımsız değişken katsayısı: 0,1879) olarak gerçekleşmiştir. Mükemmeliyetçilik odaklı satın alma eğiliminin mobil cihazlardan alışveriş yapma niyetine etkisinde sosyal medya reklamlarının bilgi saylayıcı olma özelliğinin aracılık rolünün incelendiği modelin toplam açıklama düzeyi ise \%30,62 (Bağımsız değişken katsayısı: 0,1011) olarak gerçekleşmiştir. Ancak aracı değişkenin modele dâhil olması ile birlikte Mükemmeliyetçilik odaklı satın alma eğiliminin, mobil satın alma niyetini açıklama düzeyini ifade eden katsayının düştüğü görülmektedir. Katsayı değerindeki düşüşe bağlı olarak; Mükemmeliyetçilik odaklı satın alma eğilimindeki tüketicilerin mobil cihazlardan satın alma işlemi gerçekleştirmelerinde sosyal medya reklamlarının bilgi sağlama özelliğinin kısmi aracılık etkisine sahip olduğunu ifade etmek mümkündür.

Marka odaklı satın alma eğiliminin mobil cihazlardan alışveriş yapma niyetine etkisi \%09,91 (Bağımsız değişken katsayısı: 0,3972) olarak gerçekleşmiştir. Marka odaklı satın alma eğiliminin mobil cihazlardan alışveriş yapma niyetine etkisinde sosyal medya reklamlarının bilgi sağlama 
özelliğinin aracılık rolünün incelendiği modelin toplam açıklama düzeyi ise \%33,18 (Bağımsız değişken katsayısı: 0,2271) olarak gerçekleşmiştir. Ancak aracı değişkenin modele dâhil olması ile birlikte marka odaklı satın alma eğiliminin, mobil satın alma niyetini açılama düzeyini ifade eden katsayının düştüğü görülmektedir. Katsayı değerindeki düşüşe bağlı olarak; marka odaklı satın alma eğilimindeki tüketicilerin mobil cihazlardan satın alma işlemi gerçekleştirmelerinde sosyal medya reklamlarının bilgi sağlama özelliğinin kısmi aracılık etkisine sahip olduğunu ifade etmek mümkündür.

Eğlence ve haz odaklı satın alma eğiliminin mobil cihazlardan alışveriş yapma niyetine etkisi \%11,95 (Bağımsız değişken katsayısı: 0,3132) olarak gerçekleşmiştir. Eğlence ve haz odaklı eğilimle satın almanın mobil cihazlardan alışveriş yapma niyetine etkisinde sosyal medya reklamlarının bilgi sağlama özelliğinin aracılık rolünün incelendiği modelin toplam açıklama düzeyi ise $\% 33,88$ (Bağımsız değişken katsayısı: 0,1825) olarak gerçekleşmiştir. Ancak aracı değișkenin modele dâhil olması ile birlikte eğlence ve haz odaklı satın alma eğiliminin, mobil satın alma niyetini açıklama düzeyini ifade eden katsayının düştüğü görülmektedir. Katsayı değerindeki düşüşe bağlı olarak; eğlence ve haz odaklı satın alma eğilimindeki tüketicilerin mobil cihazlardan satın alma işlemi gerçekleştirmelerinde sosyal medya reklamlarının bilgi sağlayıcı olma özelliğinin kısmi aracılık etkisine sahip olduğunu ifade etmek mümkündür.

Karmaşa yaşayanların satın alma eğiliminin mobil cihazlardan alışveriş yapma niyetine etkisi \%6,15 (Bağımsız değişken katsayısı: 0,2603) olarak gerçekleşmiştir. Eğlence ve haz odaklı eğilimle satın almanın mobil cihazlardan alışveriş yapma niyetine etkisinde sosyal medya reklamlarının güvenilir olma özelliğinin aracılık rolünün incelendiği modelin toplam açıklama düzeyi ise $\% 31,44$ (Bağımsız değişken katsayısı: 0,1221) olarak gerçekleşmiştir. Ancak aracı değişkenin modele dâhil olması ile birlikte karmaşa yaşayanların satın alma eğiliminin, mobil satın alma niyetini açıklama düzeyini ifade eden katsayının düştüğü görülmektedir. Katsayı değerindeki düşüşe bağlı olarak; karmaşa yaşayanların satın alma eğilimindeki tüketicilerin mobil cihazlardan satın alma işlemi gerçekleştirmelerinde sosyal medya reklamlarının bilgi sağlama özelliğinin kısmi aracılık etkisine sahip olduğunu ifade etmek mümkündür.

Dürtüsel alışveriş ile fiyat odaklı alışverişin mobil cihazlardan satın almaya etkisinde sosyal medya reklamlarının bilgi sağlama özelliğinin aracılık rolünün olmadığı tespit edilmiştir. Araştırma bulgularına göre hipotezlerin desteklenme ve desteklenmeme durumu şu şekildedir;

\begin{tabular}{|c|c|}
\hline Hipotez & $\begin{array}{l}\text { Desteklenme } \\
\text { durumu }\end{array}$ \\
\hline $\mathrm{H}_{1}$ : Tüketicilerin satın alma tarzlarının mobil alışveriş niyeti üzerinde anlamlı bir etkisi vardır. & Kismen desteklendi \\
\hline $\begin{array}{l}\mathrm{H}_{2} \text { : Tüketicilerin satın alma tarzlarının sosyal medya reklamlarının özelliklerinin algılanması } \\
\text { üzerinde anlamlı bir etkisi vardır. }\end{array}$ & Kismen desteklendi \\
\hline $\begin{array}{l}\mathrm{H}_{3} \text { : Sosyal medya reklamlarının özelliklerinin algılanma şeklinin mobil alışveriş niyeti üzerinde } \\
\text { anlamlı bir etkisi vardır. }\end{array}$ & Kismen desteklendi \\
\hline
\end{tabular}

\section{SONUÇLAR}

Tüketiciler, satın alma tarzlarına göre farklı satın alma davranışları gösterebilmektedir. Araştırma kapsamında tüketicilerin satın alma tarzlarına göre sosyal medya reklamlarını algılama ve sonrasında mobil cihazlarını kullanarak mal ve hizmetleri satın alma süreçleri tespit edilmeye çalışılmıştır. Araştırma, tüketicilerin satın alma tarzlarının mobil cihazlardan satın alma niyetine etkisinde sosyal medya reklamlarının aracılık rolünün tespit edilmesi amacıyla yapılmıştır. Araştırma kapsamında yer alan tüketicilerin satın alma tarzları, sosyal medya reklamlarını algılayışları ve mobil satın alma niyetleri ile ilgili vermiş oldukları cevaplar incelendiğinde; alışverişlerinde yüksek düzeyde dikkate sahip oldukları, kalite algılarının yüksek olduğu, fiyat odaklı satın alma eğilimlerinin olduğu, marka-fiyat bilinçlerinin ise düşük olduğu görülmüştür. Eğlence ve haz odaklı alışveriş yapma ve alışverişlerde karmaşa yaşama düzeylerinin ise kararsız seviyede olduğu görülmüştür. Tüketicilerin sosyal medya reklamlarının bilgi sunma özelliği hakkında kararsız oldukları görülürken, sosyal medya reklamlarının güvenilirliği, ekonomiye katkısı ve eğlenceli oluşu ile ilgili ise olumsuz görüşler belirtmişlerdir. Yani tüketicilerin sosyal medya reklamlarını genellikle olumsuz şekilde 
değerlendirdiklerini ifade etmek mümkündür. Tüketicilerin mobil cihazlarını kullanarak satın alma işlemi yapma eğilimleri de düşük düzeydedir.

Aracılık etkisinin tespit edilebilmesi için yapılan analizler sonucunda sosyal medya reklamlarının eğlenceli olması, mükemmeliyetçilik odaklı olan, marka odağı yüksek olan, eğlence ve haz odaklı olan tüketiciler ve karmaşa yaşayan tüketicilerin mobil cihazlarını kullanarak satın alma eğilimlerinin artmasına neden olduğu görülmüştür. Söz konusu tüketicilerin sosyal medyada gördükleri reklamları eğlenceli bulduklarında, reklamlardaki ürünleri kaliteli, haz verici ve karmaşa azaltıcı olarak algılayarak mobil cihazlardan satın alma işlemi gerçekleştirdiklerini düşünmek mümkündür.

Marka odaklılığı yüksek olan tüketiciler, eğlence ve haz odaklı tüketiciler ve karmaşa yaşayan tüketicilerin mobil cihazlarını kullanarak alışveriş yapma eğilimlerinde sosyal medya reklamlarının ekonomiye katkı sağlayan bir içeriğe sahip olması etkili bir faktördür. Söz konusu tüketicilerin mobil cihazlar üzerinden satın alma işlemi gerçekleştirmeden önce, sosyal medyada mal ve hizmetler hakkında izledikleri reklamların ekonomiye katkı sağladığını algılamaları, mal ve hizmetleri satın alma eğilimleri arttırabilmektedir.

Mükemmeliyetçilik odaklı olan, marka odaklılı̆̆ yüksek olan, eğlence ve haz odaklı olan tüketicilerin mobil cihazları üzerinden mal ve hizmet satın alma işlemlerinde, izledikleri sosyal medya reklamlarının güvenilir olarak algılanmasının etkili olduğu görülmüştür. Eğer söz konusu tüketiciler, satın alacakları mal ve hizmetler hakkında sosyal medyada gördükleri reklamları güvenilir olarak algılarlarsa mobil cihazlarını kullanarak satın alma eğilimleri artmaktadır.

Mükemmeliyetçilik odaklı olan tüketiciler, marka odaklılığı yüksek olan tüketiciler, eğlence ve haz odaklı tüketiciler ve karmaşa yaşayan tüketicilerin mobil cihazlarından yapacakları alışverişlerde sosyal medya üzerinden gördükleri reklamların bilgi içerikli olmasının etkili olduğu görülmüştür. Söz konusu tüketiciler mobil cihazlarından alışveriş yapmadan önce, alışveriş yapacakları ürünler hakkında, sosyal medyada gördükleri reklamları bilgilendirici nitelikte olarak algılarlarsa, mobil cihazlarından bu mal ve hizmetleri satın alma eğilimleri artmaktadır.

Tüketicilerin satın alma tarzlarının mobil cihazları kullanarak satın alma eğilimlerinin düşük düzeyde, sosyal medya reklamlarının özelliklerinin tüketicilerin mobil cihazlarını kullanarak satın alma eğilimlerini daha yüksek düzeyde açıkladığı tespit edilmiştir. Tüketici satın alma tarzlarının mobil satın alma eğilimine etkisinde sosyal medya reklamlarının ise kısmi aracılık etkisinin olduğu sonucuna ulaşılmıştır. Elde edilen sonuçlar doğrultusunda, tüketicilerin mobil cihazlarını kullanarak bir mal ya da hizmeti satın almaya niyetlerinde sosyal medya reklamlarını bilgi sağlayıcı, güvenilir, eğlenceli ve ekonomik olarak katkı sağlayan özellikte olduğunu algıladığında, satın alma eğilimleri daha yüksek düzeye ulaşmaktadır.

Araştırmada tüketicilerin satın alma tarzlarının mobil satın alma niyetine etkisinde sosyal medya reklamlarının aracılık rolü tespit edilmeye çalışılmıştır. Alanyazında yapılan incelemeler sonucunda bu araştırmada incelenen modelin daha önce incelenmediği görülmektedir. Bu yüzden, araştırmadan elde edilen ampirik kanıtların desteklenebilmesi için ikili ilişkilerden örnekler sunulmaktadır. Tüketicilerin eğlence bazlı alışverişleri ile mobil satın alma eğilimleri arasındaki ilişkiler, Wu ve Ye (2013), Jung vd. (2016) tarafından yapılan çalışma sonuçları ile benzerlik göstermektedir. Sosyal medya reklamlarının içerik özelliklerinin tüketicilerin satın alma niyetine etkisi hakkındaki sonuçlar ise Aksoy ve Gür (2018), Lee ve Hong (2016), Chu vd. (2013), Azeem ve Haq (2012) tarafından yapılan çalışma sonuçları ile benzerlik göstermektedir. Reklamların eğlenceli olarak algılanmasının mobil cihazlar üzerinden satın alma eğilimini arttırması ile ilgili bulgular Yang ve Kim (2012) tarafından elde edilen bulgularla benzerlik göstermektedir. Sarkar vd. (2020) tarafindan yapılan çalışmada, tüketicilerin mükemmeliyetçi ve fiyat odaklı olarak satın alma eğiliminde olmalarının mobil cihazlardan satın alma eğilimini arttırması ile ilgili bulguların, bu araştırmada ulaşılan sonuçlar ile benzer olduğunu ifade etmek mümkündür.

Ayrıca sosyal medya reklamlarının tüketicilerin karar verme süreçlerini kolaylaştırıcı, çelişkileri azaltıcı, tüketiciyi doğru şekilde yönlendirici, ekonomik katkı sağlayıcı, reklamları izleyen ya da gören kişileri eğlendirici şekilde tasarlanması önerilmektedir. Söz konusu özelliklere göre oluşturulacak sosyal medya reklamları ile tüketicilerin istek ve ihtiyaçlarının daha yüksek düzeyde 
tatmin edilmesi sağlanabilir. Son olarak, tüketici satın alma tarzı, sosyal medya reklamları ve mobil alışveriş konularında yapılacak çalışmaların mal-hizmet bazlı olarak gerçekleştirilmesi, tüketicilerin satın alma davranışlarının daha iyi açıklanmasına katkıda bulunabilecektir. Satın alınacak mal ve hizmetin özellikleri ve tüketicilerin satın alma davranışları sosyal medya reklamlarını algılama biçimleri açısından önemli olabilmekte, farklı satın alma tarzına sahip tüketiciler mal ve hizmet kategorilerine göre farklı satın alma eğilimleri gösterebilmektedir.

Etik Beyan: Bu çalışmada kullanılan anket yöntemi için Beykent Üniversitesi Etik Kurulu'ndan 11.05.2020 tarihli toplantısında izin alınmıștır. Aksi bir durumun tespiti halinde AKAD Dergisinin hiçbir sorumluluğu olmayıp, tüm sorumluluk çalışmanın yazar (lar) ına aittir.

Yazar Katkı Beyanı: 1. Yazarın katkı oranı \%34, 2. Yazarın katkı oranı \%33, 3. Yazarın katkı oranı ise \%33'tür.

Çıkar Beyanı: Yazarlar arasında çıkar çatışması yoktur.

Ethics Statement: For the survey method used in this study, permission was obtained from the Beykent University Ethics Committee at its meeting dated 11.05.2020. In case of detection of a contrary situation, AKAD Journal has no responsibility and all responsibility belongs to the author (s) of the study.

Author Contributions Statement: 1st author's contribution rate 34\%, 2nd author's contribution rate $33 \%$, 3rd author's contribution rate 33\%.

Conflict of Interest: There is no conflict of interest among the authors.

\section{KAYNAKÇA}

Ada, S., Çiçek, B., \& Kaynakyeşil, G. (2013). Çevrimiçi sosyal ă̆ sitesi kullanımını etkileyen motive edici faktörler üzerine bir araştırma. Akademik Bilişim Konferansı Bildiriler Kitabı, 15, 669673. https://ab.org.tr/ab13/kitap/ada cicek AB13.pdf

Akkaya, D. T., Akyol, A., \& Şimşek, G. G. (2018). Sosyal medya reklamcılığında tüketici algılarının tutum, davranış ve satın alma niyeti üzerine etkisi. Marmara Üniversitesi Iktisadi ve İdari Bilimler Dergisi, 39(2), 361-388. https://doi.org/10.14780/muiibd.384073.

Aksoy, H., \& Gür, A. (2018). Üniversite öğrencilerinin sosyal medya reklamlarına ilişkin algılarının satın alma niyeti üzerindeki etkisi: Gaziantep Üniversitesi örneği. Cumhuriyet Üniversitesi $\begin{array}{llll}\text { İktisadi ve Idari Bilimler } & \text { Dergisi, } & 19(1), & 129-148 .\end{array}$ https://dergipark.org.tr/tr/pub/cumuiibf/issue/37183/396639

Alnıaçı, Ü. (2012). Satın alma tarzları ve SMS reklamlarına yönelik tutumlar: Genç tüketiciler üzerinde bir araştırma. Pazarlama ve Pazarlama Araştırmaları Dergisi, 5(9), 1-20. https://dergipark.org.tr/tr/pub/ppad/issue/61012/906090

Amjad, M., Javed, R., \& Jaskani, N. H. (2015). Examining attitudes and beliefs towards online advertising in Pakistan. International Journal of Scientific ve Engineering Research, 6(1), 463480. https://www.ijser.org/researchpaper/Examining-Attitudes-and-Beliefs-towards-OnlineAdvertising-in-Pakistan.pdf

Azeem, A., \& Haq, Z. (2012). Perception towards internet advertising: A study with reference to three different demographic groups. Global Business and Management Research, 4(1), 28-45. https://docplayer.net/6721453-Perception-towards-internet-advertising-a-study-with-referenceto-three-different-demographic-groups.html

Battallar, Z., \& Cömert, M. (2015). Tüketicilerin tercihlerinde sosyal medyadaki reklamların etkisi. Turizm Akademik Dergisi, 2(1), 39-48. https://dergipark.org.tr/tr/download/article-file/153077

Büyüköztürk, Ş., Kılıç Çakmak, E., Akgün, Ö. E., Karadeniz, Ş., \& Demirel, F. (2016). Bilimsel araştırma yöntemleri. Pegem Akademi. http://www.pegem.net/dosyalar/dokuman/28022012172735bilimsel\%20aras.\%20y.11.bask\%C4 \%B1.pdf

Caladine, R. (2008). Enhancing e-learning with media-rich content and interactions. Information Science Publishing. https://doi.org/10.4018/978-1-59904-732-4 
Ceylan, H. H. (2013). Tüketici tipleri envanterinin Türk kültürüne uyarlanması. Çukurova Üniversitesi $\begin{array}{llll}\text { Sosyal Bilimler } & \text { Enstitüsü }\end{array}$ https://dergipark.org.tr/tr/pub/cusosbil/issue/4393/60446

Chong, A. Y. L. (2013). A two-staged SEM-neural network approach for understanding and predicting the determinants of m-commerce adoption. Expert Systems with Applications, 40(4), 1240-1247. https://doi.org/10.1016/j.eswa.2012.08.067.

Chu, S. C., Kamal, S., \& Kim, Y. (2013). Understanding consumers' responses toward social media advertising and purchase intention toward luxury products. Journal of Global Fashion Marketing, 4(3), 158-174, https://doi.org/10.1080/20932685.2013.790709.

Dehghani, M., \& Tumer, M. (2015). A research on effectiveness of Facebook advertising on enhancing purchase intention of consumers. Computers in Human Behavior, 49, 597-600. https://doi.org/10.1016/j.chb.2015.03.051.

Ducoffe, R. H. (1996). Advertising value and advertising on the web-Blog@ management. Journal of Advertising Research, 36(5), 21-32. https://doi.org/10.1080/135272600750036364

Dursun, İ., Alnıaçı, Ü., \& Tümer Kabadayı, E. (2010). Tüketici karar verme tarzları ölçeği: Türk tüketicisi için uyarlama. Ulusal Pazarlama Kongresi Bildiriler Kitabı, 15, 320-325. http://www.pazarlama.org.tr/uploads/files/upk15.pdf

Dursun, İ. Alnıaçı, Ü., \& Tümer Kabadayı, E. (2013). Tüketici karar verme tarzları ölçeği: Yapısı ve boyutları. Issletme Dergisi, 9(19), 293-304. https://doi.org/10.11122/ijmeb.2013.9.19.418

Engizek, N., \& Şekerkaya, A. (2016). X ve Y kuşağı kadınlarının karar verme tarzları bakımından incelenmesi. Mustafa Kemal Üniversitesi Sosyal Bilimler Enstitüsü Dergisi, 13(36), 242-271. https://dergipark.org.tr/tr/download/article-file/683973

Eriksson, N., Rosenbröijer, C. J., \& Fagerström, A. (2017). The relationship between young consumers' decision-making styles and propensity to shop clothing online with a smartphone. Procedia Computer Science, 121(2017), 519-524. https://doi.org/10.1016/j.procs.2017.11.069.

Gao, L., Waechter, K. A., \& Bai, X. (2015). Understanding consumers' continuance intention towards mobile purchase: A theoretical framework and empirical study-A case of China. Computers in Human Behavior, 53(2015), 249-262, https://doi.org/10.1016/j.chb.2015.07.014.

George, D., \& Mallery, M. (2010). SPSS for Windows step by step: A simple guide and reference. 17.0 update (10a Ed.), Pearson. https://wps.ablongman.com/wps/media/objects/385/394732/george4answers.pdf

Gökalan, B. Y. (2009). Dayanıkl tüketim malları sektöründe ülke orijininin tüketicinin satın alma niyetine etkisi [Yayınlanmamış Doktora Tezi, Ankara Üniversitesi] Yüksek Öğretim Kurumu Tez Merkezi. https://tez.yok.gov.tr/UlusalTezMerkezi/tezSorguSonucYeni.jsp

Hafstrom, J. L., Chae, J. S., \& Chung, Y. S. (1992). Consumer decision-making style: Comparison between United States and Korean young consumers. The Journal of Consumer Affairs, 26(1), 146-158. https://www.jstor.org/stable/23859483

Hair, J., Black, W., Babin, B., \& Anderson, R. (2014). Multivariate data analysis. (7th ed.). Pearson Education Limited.

Hayes, A. F. (2018). Introduction to mediation, moderation, and conditional process analysis: A regression-based perspective (2nd ed.). Guilford Publications.

İslamoğlu, A. H. (2009). Temel pazarlama bilgisi (3. baskı). Beta Basım.

Jung, J., Shim, S. W., Jin, H. S., \& Khang, H. (2016). Factors affecting attitudes and behavioural intention towards social networking advertising: A case of Facebook users in South Korea. International Journal of Advertising, 35(2), 248-265, https://doi.org/10.1080/02650487.2015.1014777. 
Kayapınar, Ö., Yürük Kayapınar, P., \& Tan, Ö. (2017). Sosyal medya reklamlarına yönelik tüketici algıları ile e-sadakat arasındaki ilişkide markaya yönelik tutumun rolü. İşletme Araştırmaları Dergisi, 9(4), 472-494. https://doi.org/10.20491/isarder.2017.342.

Keating, R. T., Hendy, H. M., \& Can, S. H. (2016). Demographic and psychosocial variables associated with good and bad perceptions of social media use. Computers in Human Behavior, 57, 93-98. https://doi.org/10.1016/j.chb.2015.12.002.

Koç Başaran, Y. (2017). Sosyal bilimlerde örnekleme kuramı. Akademik Sosyal Araştırmalar Dergisi, 5(47), 480-495. https://doi.org/10.16992/ASOS.12368.

Köker, N. E., Köseoğlu, Ö., \& Yakın, M. (2018). E-satın alma niyeti internet ve sosyal medya kullanımı tarafından pekiştiriliyor mu? Üniversite öğrencileri üzerine nicel bir araştırma. Erciyes Illetişim Dergisi, 5(4), 143-162. https://doi.org/10.17680/erciyesiletisim.422394

Kurtuluş, K. (2015). Araştırma yöntemleri. Türkmen Kitabevi.

Lee, J., \& Hong, I. B. (2016). Predicting positive user responses to social media advertising: The roles of emotional appeal, informativeness, and creativity. International Journal of Information Management, 36(3), 360-373, https://doi.org/10.1016/j.ijinfomgt.2016.01.001.

Leng, C. Y., \& Botelho, D. (2010). How does national culture impact on consumers-decision-making styles? A cross cultural study in Brazil, the United States and Japan. BAR-Brazilian Administration Review, 7(3), 260-275. https://doi.org/10.1590/S1807-76922010000300004

MacKenzie, S. B., \& Lutz, R. J. (1989). An empirical examination of the structural antecedents of attitude toward the ad in an advertising pretesting context. Journal of Marketing, 53(2), 48-65. https://doi.org/10.2307/1251413

Madahi, A., \& Sukati, I. (2012). The effect of external factors on purchase intention amongst young generation in Malaysia. International Business Research, 5(8), 153-159, https://doi.org/10.5539/ibr.v5n8p153.

Mehta, R., \& Dixit, G. (2016). Consumer decision making styles in developed and developing markets: A cross-country comparison. Journal of Retailing and Consumer Services, 33, 202208, https://doi.org/10.1016/j.jretconser.2016.09.002.

Özçiftçi, V. (2020). Sosyal medyanın tüketicilerin satın alma niyeti üzerindeki etkisi. Ahi Evran Üniversitesi Sosyal Bilimler Enstitüsü Dergisi, 6(1), 206-223. https://doi.org/10.31592/aeusbed.634148.

Özgüven, N. (2011). Tüketicilerin online alışverişe karşı tutumları ile demografik özellikleri arasındaki ilişkinin analizi. KMÜ Sosyal ve Ekonomik Araştırmalar Dergisi, 13(21), 47-54. https://dergipark.org.tr/tr/pub/kmusekad/issue/10215/125553

Pantano, E., \& Priporas, C. V. (2016). The effect of mobile retailing on consumers' purchasing experiences: A dynamic perspective. Computers in Human Behavior, 61, 548-555. https://doi.org/10.1016/j.chb.2016.03.071

Pınar, M., Yılmaz, K. G. \& Güngördü Belbă̆, A. (2019). Sosyal ağlar üzerinden yapılan ticarette tüketici satın alma niyetini etkileyen faktörlerin belirlenmesi: Instagram kullanıcıları üzerine bir araştırma. Tüketici ve Tüketim Araştırmaları Dergisi, 11(2), 357-378. http://betadergi.com/ttad/yonetim/icerik/makaleler/243-published.pdf

Sarıalp, S., \& Tengilimoğlu, D. (2020). Sağlık sektöründe, tüketici satın alma davranışında sosyal medya reklamlarının etik boyutu. Hacettepe Sağllk İdaresi Dergisi, 23(1), 93-114. https://dergipark.org.tr/tr/pub/hacettepesid/issue/53213/706474

Sarkar, S., Khare, A., \& Sadachar, A. (2019). Influence of consumer decision-making styles on use of mobile shopping application. Benchmarking: An International Journal, 27(1), 1-20. https://doi.org/10.1108/BIJ-07-2018-0208 
Shim, S. (1996). Adolescent consumer decision-making styles: The consumer socialization perspective. Psychology ve Marketing, 13(6), 547-569. https://doi.org/10.1002/(SICI)15206793(199609)13:6<547::AID-MAR2>3.0.CO;2-8

Sobel, M. E. (1982). Asymptotic confidence intervals for indirect effects in structural equation models. Sociological Methodology, 13, 290-312. https://doi.org/10.2307/270723

Sobel, M. E. (1986). Some new results on indirect effects and their standard errors in covariance structure. Sociological Methodology, 16, 159-186. https://doi.org/10.2307/270922

Söyleyici, G. T., \& Çetinkaya Bozkurt, Ö. (2017). Sosyal medya ve tüketici davranışları ilişkisi: Türkiye'deki sosyal medya kullanıcıları üzerine bir araştırma. Kesit Akademi Dergisi, 3(9), 3654. https://doi.org/10.18020/kesit.1200

Sproles, G. B., \& Kendall, E. L. (1986). A methodology for profiling consumers' decision making styles. The Journal of Consumer Affairs, 20(2), 267-279. https://www.jstor.org/stable/23859027

Şener, A., \& Yücel, S. (2020). Sosyal medyanın Y kuşağı satın alma davranışları üzerindeki etkisi: Bir literatür incelemesi. Dumlupınar Üniversitesi Sosyal Bilimler Dergisi, 65, 265-284. https://dergipark.org.tr/tr/pub/dpusbe/issue/56154/741540

Tabachnick, B. G., \& Fidell, L. S. (2013). Using multivariate statistics (6th ed.). Pearson.

Ting, H., Run, E. C., \& Thurasamy, R. (2015). Young adults' attitude towards advertising: A multigroup analysis by ethnicity. Revista Brasileira De Gestão De Negócios, 17(54), 769-787. https://doi.org/10.7819/rbgn.v17i54.1777.

TÜSİAD (2019). E-ticaretin gelişimi, sinırları aşılması ve yeni normlar, http://www.tubisad.org.tr/tr/images/pdf/dd-tusiad-eticaret-raporu-2019.pdf.

Ulama, Ş., \& Koç, D. E. (2019). Kastamonu ilinde turizm eğitimi alan üniversite öğrencilerinin sosyal medya reklamlarına yönelik algılarının satın alma davranışlarına etkisi. Gastroia: Journal of Gastronomy and Travel Research, 3(3), 381-399. https://doi.org/10.32958/gastoria.466427

Varkaris, E., \& Neuhofer, B. (2017). The influence of social media on the consumers' hotel decision journey. Journal of Hospitality and Tourism Technology, 8(1), 101-118. https://doi.org/10.1108/JHTT-09-2016-0058

Wei, K. K., Jerame, T., \& Shan, L. W. (2010). Online advertising: A study of Malaysian consumers. International Journal of Business and Information, 5(2), 111-134. https://doi.org/10.2139/ssrn.1644802

Wu, Y. L., \& Ye, Y. S. (2013). Understanding impulsive buying behavior in mobile commerce. PACIS 2013 Proceedings. 142. http://aisel.aisnet.org/pacis2013/142.

Xie, K., \& Lee, Y. J. (2015). Social media and brand purchase: Quantifying the effects of exposures to earned and owned social media activities in a two-stage decision making model. Journal of $\begin{array}{llll}\text { Management Information } & \text { Systems, }\end{array}$ https://doi.org/10.1080/07421222.2015.1063297

Yang, K., \& Kim, H. (2012). Mobile shopping motivation: An application of multiple discriminant analysis. International Journal of Retail ve Distribution Management, 40(10), 778-789. https://doi.org/10.1108/09590551211263182

Yılmaz, V., \& İlhan Dalbudak, Z. (2018). Aracı değişken etkisinin incelenmesi: Yüksek hızlı tren işletmeciliği üzerine bir uygulama. Uluslararası Yönetim İktisat ve İsletme Dergisi, 14(2), 517 534. https://dergipark.org.tr/tr/download/article-file/1123907

Yüksekbilgili, Z. (2016). Tüketici karar verme tarzlarının kuşaklara göre değerlendirilmesi. Elektronik Sosyal Bilimler Dergisi, 15(59), 1392-1402. https://doi.org/10.17755/esosder.263240 